\title{
Spatial and temporal trend in the abundance and distribution of gurnards (Pisces: Triglidae) in the northern Mediterranean Sea
}

\author{
Francesco Colloca ${ }^{1,2}$, Giacomo Milisenda ${ }^{3}$, Francesca Capezzuto ${ }^{4}$, Alessandro Cau ${ }^{5}$, \\ Germana Garofalo $^{1}$, Angélique Jadaud ${ }^{6}$, Sotiris Kiparissis ${ }^{7}$, Reno Micallef ${ }^{8}$, \\ Stefano Montanini ${ }^{9}$, Ioannis Thasitis ${ }^{10}$, Maria Vallisneri ${ }^{9}$, Alessandro Voliani ${ }^{11}$, \\ Nedo Vrgoc ${ }^{12}$, Walter Zupa ${ }^{13}$, Francesc Ordines ${ }^{14}$ \\ ${ }^{1}$ National Research Council, Istituto per le Risorse Biologiche e le Biotecnologie Marine (CNR-IRBIM), \\ Mazara del Vallo (TP), Italy. \\ (FC) (Corresponding author) E-mail: francesco.colloca@ cnr.it. ORCID iD: https://orcid.org/0000-0002-0574-2893 \\ (GG) E-mail: germana.garofalo@iamc.cnr.it. ORCID iD: https://orcid.org/0000-0001-9117-6252 \\ ${ }^{2}$ Department of Biology and Biotechnology “C. Darwin” BBCD, Sapienza University of Rome, Italy. \\ ${ }^{3}$ Stazione Zoologica Anton Dohrn, Lungomare Cristoforo Colombo (ex complesso Roosevelt), 90142 Palermo, Italy. \\ (GM) E-mail: giacomo.milisenda@szn.it. ORCID iD: https://orcid.org/0000-0003-1334-9749 \\ ${ }^{4}$ Department of Biology, University of Bari Aldo Moro, Bari, Italy. \\ (FC) E-mail: francesca.capezzuto@uniba.it. ORCID iD: https://orcid.org/0000-0002-1498-0228 \\ ${ }^{5}$ Department of Life and Environmental Sciences, Via Tommaso Fiorelli 1, University of Cagliari, Cagliari, Italy. \\ (AC) E-mail: alessandrocau@ unica.it. ORCID iD: https://orcid.org/0000-0003-4082-7531 \\ ${ }^{6}$ MARBEC - IFREMER, CNRS, IRD, Université Montpellier 2, Avenue Jean Monnet, CS 30171, 34203 Sète Cedex, France. \\ (AJ) E-mail: Angelique.Jadaud@ifremer.fr. ORCID iD: https://orcid.org/0000-0001-6858-3570 \\ ${ }^{7}$ Hellenic Agricultural Organization-DEMETER, Fisheries Research Institute of Kavala, 64007 Nea Peramos, Kavala, Greece. \\ (SK) E-mail: skipariss@inale.gr. ORCID iD: https://orcid.org/0000-0002-0587-8889 \\ ${ }^{8}$ Ministry for the Environment, Sustainable Development and Climate Change, Marsa, Malta. \\ (RM) E-mail: reno.micallef@gov.mt. ORCID iD: https://orcid.org/0000-0003-1921-508X \\ ${ }^{9}$ Department of Biological, Geological and Environmental Sciences (BIGEA), University of Bologna, Bologna, Italy. \\ (SM) E-mail: stefano.montanini2@unibo.it. ORCID iD: https://orcid.org/0000-0002-7286-7805 \\ (MV) E-mail: maria.vallisneri@unibo.it. ORCID iD: https://orcid.org/0000-0002-6323-4328 \\ ${ }^{10}$ Department of Fisheries and Marine Research (DFMR), Nicosia, Cyprus. \\ (IT) E-mail: ithasitis@dfmr.moa.gov.cy. ORCID iD: https://orcid.org/0000-0002-0940-2212 \\ ${ }^{11}$ Environmental Protection Agency Tuscany Region (ARPAT), Settore Mare, Livorno, Italy. \\ (AV) E-mail: a.voliani@ arpat.toscana.it. ORCID iD: https://orcid.org/0000-0002-0905-6284 \\ 12 Institute of Oceanography and Fisheries. Set. I. Mestrovica 63, 21000 Split, Croatia. \\ (NV) E-mail: vrgoc@izor.hr. ORCID iD: https://orcid.org/0000-0002-5208-4512 \\ ${ }^{13}$ COISPA Tecnologia \& Ricerca, Via dei Trulli 18-20, 70126 Bari, Italy. \\ (WZ) E-mail: zupa@ coispa.eu. ORCID iD: https://orcid.org/0000-0002-2058-8652 \\ ${ }^{14}$ Instituto Español de Oceanografía, Centre Oceanogràfic de les Balears, Palma de Mallorca, Spain. \\ (FO) E-mail: xisco.ordinas@ba.ieo.es. ORCID iD: https://orcid.org/0000-0002-2456-2214
}

\begin{abstract}
Summary: In this study we investigated the spatio-temporal distribution of gurnards ( 8 species of Triglidae and one species of Peristediidae) in the northern Mediterranean Sea using 22 years of MEDITS bottom trawl survey data (1994-2015). Gurnards showed significant differences in terms of abundance, dominance and composition among geographical sub-areas and ecoregions, with the highest relative biomass $\left(B I_{y}\right)$ being found in Malta, eastern Corsica, the Balearic Islands and the eastern Ionian Sea. The lowest gurnards $B I_{y}$ were observed in the highly exploited areas of the western Mediterranean and the Adriatic Sea, where the largest number of species with a negative linear trend in $B I_{y}$ was also found. The temporal trends in species abundances highlighted a general decrease for the coastal species (C. lucerna, C. lastoviza, C. obscurus) as compared with the species inhabiting the deep continental shelf and slope (T. lyra, $P$. cataphractum). The results provide for the first time an overview of the spatiotemporal trend in the abundance of gurnards over the wide spatial scale of the northern Mediterranean Sea, also suggesting the possible use of these species as indicators for monitoring the impact of fishing pressure on demersal fish assemblages.
\end{abstract}

Keywords: Triglidae; Mediterranean Sea; trawl by-catch; MEDITS; fishing pressure.

\section{Abundancia y distribución de los gurnardos en el norte del Mediterráneo}

Resumen: En este estudio hemos investigado la distribución espacio-temporal de los gurnardos (8 especies de Triglidae y 1 especie de Peristediidae) en el norte del Mediterráneo usando 22 años de datos de la campaña de pesca de arrastre ME- 
DITS (1994-2015). Los gurnardos mostraron diferencias significativas en la abundancia, dominancia y composición entre las distintas sub-areas geográficas (GSAs) y las ecoregiones, encontrándose las mayores biomasas relativas $\left(B I_{y}\right)$ en Malta, el este de Córcega, las Islas Baleares y el oeste del mar Jónico. Por otro lado, los menores valores de $B I_{y}$ fueron observados en las áreas más explotadas del oeste del Mediterráneo y del Mar Adriático, donde también se observó el mayor número de especies con una tendencia lineal negativa en relación a $B I_{y}$. La tendencia temporal en la abundancia de especies evidenció una disminución general en las especies costeras (C. lucerna, C. lastoviza, C. obscurus) respecto a las especies que habitan la profunda plataforma y pendiente continentales (T. lyra, P. cataphractum). Los resultados proporcionan por primera vez una visión general de las tendencias espacio-temporales en la abundancia de los gurnardos en la amplia escala espacial del norte del Mediterráneo, sugiriendo también la posibilidad de usar estas especies como indicadores para monitorear el impacto de la presión de pesca sobre los ensamblajes de peces demersales.

Palabras clave: Triglidae; mar Mediterráneo; captura accesoria de pesca de arrastre; MEDITS; presión de pesca.

Citation/Cómo citar este artículo: Colloca F., Milisenda G., Capezzuto F., Cau A., Garofalo G., Jadaud A., Kiparissis S., Micaleff R., Montanini S., Thasitis I., Vallisneri M., Voliani A., Vrgoc N., Zupa W., Ordines F. 2019. Spatial and temporal trend in the abundance and distribution of gurnards (Pisces: Triglidae) in the northern Mediterranean Sea. Sci. Mar. 83S1: 101-116. https://doi.org/10.3989/scimar.04856.30A

Editor: E. Massutí.

Received: February 28, 2018. Accepted: September 8, 2018. Published: March 21, 2019.

Copyright: (C) 2019 CSIC. This is an open-access article distributed under the terms of the Creative Commons Attribution 4.0 International (CC BY 4.0) License.

\section{INTRODUCTION}

The Triglidae (or gurnards) is a large family of fish of the order Scorpaeniformes, which comprises 8 genera and 125 species dwelling in tropical and temperate marine areas (Richards and Jones 2002). In the Mediterranean Sea, the family is represented by 4 genera (Eutrigla, Trigla, Chelidonichthys and Lepidotrigla) and 8 species (E. gurnardus, T. lyra, C. lucerna, $C$. cuculus, $C$. obscurus, $C$. lastoviza, $L$. cavillone and $L$. dieuzeidei). These fish are an important component of demersal assemblages in terms of biomass in both the eastern and western Mediterranean basins (Jukic-Peladic et al. 2001, Labropoulou and Papaconstantinou 2004, Massuti and Reñones 2005). Several studies have focused on the life-history traits of these species, such as growth (Papaconstantinou 1981, 1984, Colloca et al. 2003) and spawning (Papaconstantinou 1983, Vallisneri et al. 2011, 2012), feeding (Colloca et al. 1994, Morte et al. 1997, Terrats et al. 2000), as well as on other aspects related to the trophic and habitat partitioning among species (Serena et al. 1990, Tsimenides et al. 1992, Colloca et al. 2010). From an ecological perspective, the 8 gurnard species, along with the closely related African armoured searobin, Peristedion cataphractum, play similar roles in the trophic web, feeding mainly on epibenthic crustaceans (Colloca et al. 1994). Interspecific competition for food is reduced by species segregation across gradients of prey size and habitat type (Morte et al. 1997, Colloca et al. 2010, Montanini et al. 2017).

The commercial importance of the Mediterranean gurnards is not negligible. Indeed, the largest-sized species such as $C$. lucerna, T. lyra, E. gurnardus, $C$. cuculus and $C$. lastoviza are a valuable by-catch of demersal fisheries of many Mediterranean sectors (Ordines et al. 2014). Although the impact of fishing on the gurnard populations has rarely been examined, Ordines et al. (2014) pointed out that some commercially important gurnards, such as $C$. lastoviza and $C$. cuculus, have also been affected by the overall overexploitation of commercial stocks in the Mediterranean (Colloca et al. 2013, Cardinale et al. 2017). As a result, their levels of overexploitation are similar to, or even higher than, those detected for some of the most important target species such as hake and red mullet (Ordines et al. 2014). As has been demonstrated for the North Atlantic, the trends in the by-catch species (including gurnards), are quite similar to those of the principal target species, showing high exploitation rates and declining stock biomasses during the late 20th century (Cook and Heath 2018).

In the present study we investigated the abundance and distribution of 9 gurnard species over a large spatial scale covering the northern Mediterranean Sea that corresponds to EU waters. The main objective of the study was to elucidate the temporal and spatial variations in species abundances across the northern Mediterranean and to discuss the possible role of fisheries in the observed pattern.

\section{MATERIALS AND METHODS}

\section{Survey data}

The study was carried out in the framework of the international Mediterranean bottom trawl survey (MEDITS) in the northern Mediterranean using data from 1994 to 2015. The survey incorporated 17 out of the 27 geographical subareas (GSAs) into which the entire Mediterranean has been subdivided and 6 ecoregions (Spalding et al. 2007) from the northern Alboran Sea to Cyprus (Fig. 1). The gurnard data come from 23941 hauls carried out during daytime, mainly from spring to early summer (May-July) at depths of 10 to $800 \mathrm{~m}$. In GSAs 5, 15 and 25, time series were shorter or incomplete, and in GSAs 20, 22,23 and 25 some years were missing. The sampling procedure was standardized according to a common protocol (Bertrand et al. 2002, Anonymous 2017). For each of the nine species considered, a relative biomass index by haul $\left(B I_{h}\right)$ was calculated as the total 


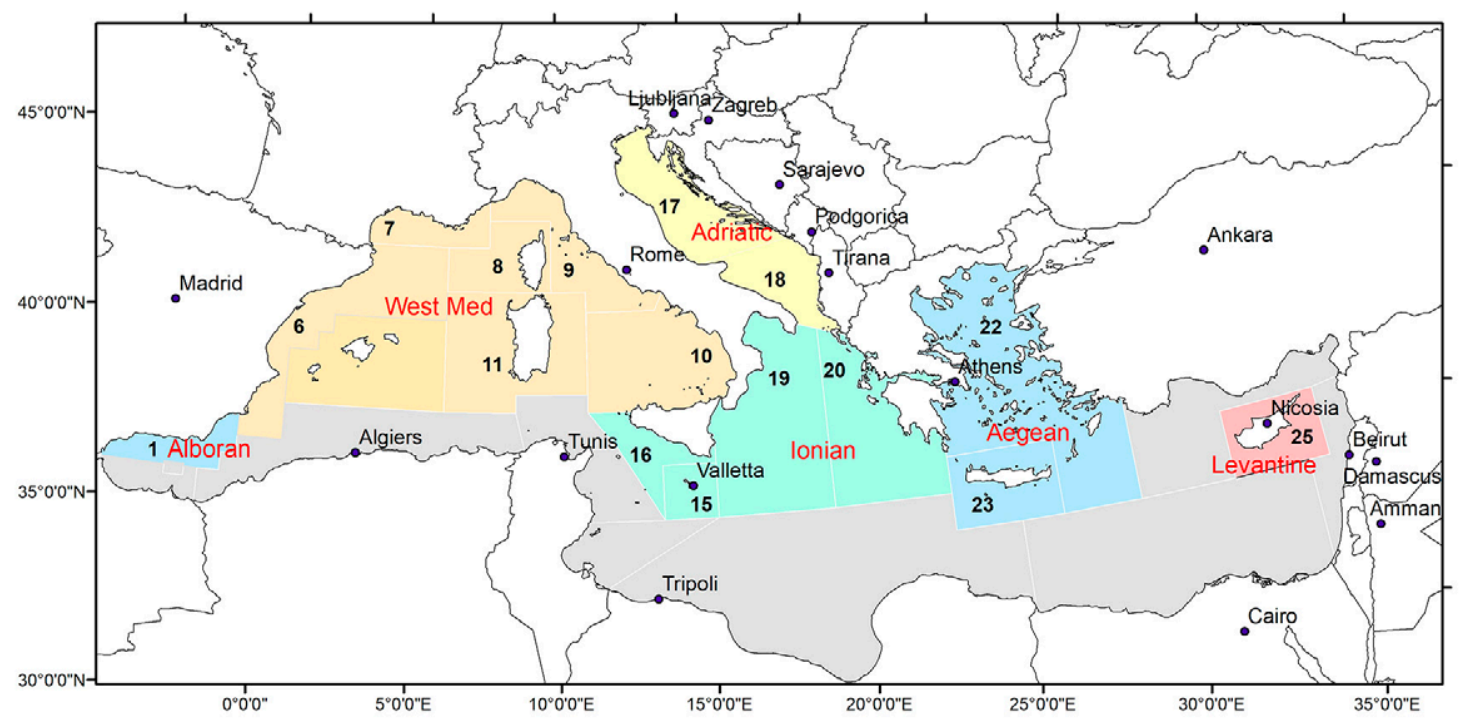

Fig. 1. - Map of the study area showing FAO geographical sub-areas (GSAs) and 6 marine ecoregions (Spalding 2007).

biomass of the specimens caught per square kilometre $\left(\mathrm{kg} \mathrm{km}^{-2}\right)$. A matrix of $9 \times 23941 B I_{h}$ values was therefore obtained.

\section{Temporal and spatial trends in relative biomass}

$B I_{h}$ values were averaged by year, GSA and ecoregion (Spalding et al. 2007) to get annual mean species biomass $\left(B I_{y}\right)$ values. The temporal trend in $B I_{y}$ was first calculated for the whole assemblage (i.e. the nine gurnard species pooled together), separately for the continental shelf (0-200 m) and the slope (200-800 m). A more detailed analysis was carried out for each single species at the ecoregion and GSA level to investigate

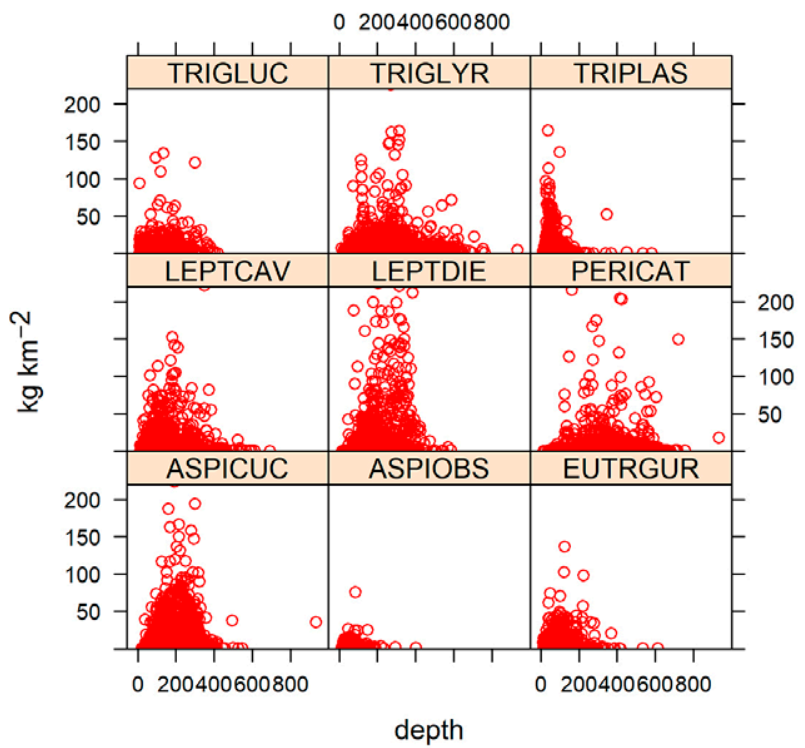

Fig. 2. - Depth distribution of the 9 species of Mediterranean gurnards. Species CPUE $\left(\mathrm{kg} \mathrm{km}^{-2}\right)$ per haul are plotted for all GSAs combined. TRIGLUC, Chelidonichthys lucerna; TRIGLYR, Trigla lyra; EUTRGUR, Eutrigla gurnardus; ASPICUC, Chelidonichthys cuculus: ASPIOBS, Chelidonichthys obscurus; LEPICAV, Lepidotrigla cavillone; LEPIDIE, Lepidotrigla dieuzeidei; TRIPLAS, Chelidonichthys lastoviza; PERICAT, Peristedion cataphractum. temporal and geographical differences in species abundance. $B I_{y}$ values of a given species in each GSA and ecoregion were calculated for the depth range where $90 \%$ of the positive hauls for that species was found (Fig. 2). This was also done in order to eliminate the outliers in the depth distributions and possible errors linked to species misidentification.

The data from the northern Adriatic (GSA 17) were analysed separately for the west (GSA 17a) and east (GSA 17b) side to account for differences due to fishing pressure and/or differences in the environmental characteristics between these two areas.

The proportional rate of change in $B I_{y}$ was calculated between the first and the last 3 years (i.e. 1994-96 and 2013-15) in GSAs 1, 6, 7, 8, 9, 10, 11, 16, 17a, 17b, $18,19,20,22$ and 23. In the case of GSAs 515 and 25, where the MEDITS time series is shorter, the change in $B I_{y}$ was estimated between 2007-09 and 2013-15 (GSA 5), and 2005-07 and 2013-15 (GSAs 15 and 25).

The non-parametric LOESS smoother was used to find a curve of best fit of species $B I_{y}$ in each GSA and ecoregion over time without assuming that the data must fit to a specific distribution shape (Cleveland et al. 1992). When a significant linear trend in species relative biomass occurred over time, this was indicated either in the GSAs or in the ecoregions. Results were finally summarized using the "traffic light" representation.

Species dominance was explored in each ecoregion by means of $\mathrm{k}$-dominance curves produced using the $\mathrm{R}$ package BiodiversityR (Kindt and Coe 2005).

\section{RESULTS}

\section{Geographical pattern in gurnard composition}

There were clear differences in gurnard composition among Mediterranean ecoregions (Fig. 3). The species guilds appeared similar in the Ionian Sea (ION) and the western Mediterranean, where the most abundant species was $C$. cuculus, accounting 

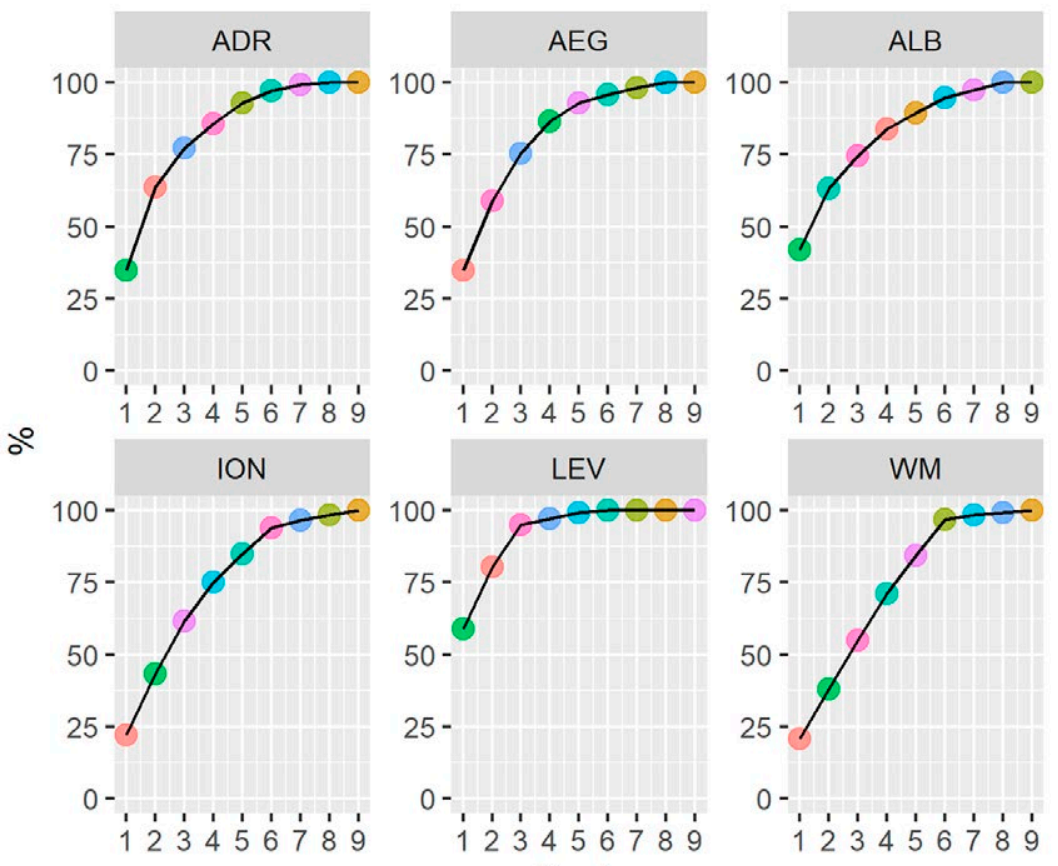

factor(species)

ASPICUC

ASPIOBS

EUTRGUR

LEPTCAV

LEPTDIE

PERICAT

TRIGLUC

TRIGLYR

TRIPLAS

Rank

Fig. 3. - Species rank-accumulation (k-dominance) curves of gurnards in the six Mediterranean ecoregions. ADR, Adriatic Sea; ALB, Alboran Sea; AEG, Aegean Sea; ION, Ionian Sea; LEV, Levantine Sea; WM, western Mediterranean. Species code as in Figure 2.

for about $25 \%$ of the observed relative biomass, also accounting for more than $80 \%$ combined with four other species (L. cavillone, L. dieuzeidei, $C$. lastoviza, T. lyra). In the Adriatic Sea (ADR), the guild was dominated by L. cavillone and C. cuculus, accounting together for more than $60 \%$ of the species biomass, while in the Alboran Sea the dominant species were the two Lepidotrigla. A very different pattern arose in the Levantine (Cyprus, GSA 25), where three species (L. cavillone, C. cuculus and C. lastoviza) accounted for more than $90 \%$ of the relative biomass. Finally, in the Aegean region, $C$. cuculus, C. lastoviza and C. lucerna accounted for about $75 \%$ of the total biomass.

\section{Trends in the overall gurnard abundance}

Gurnards were generally more abundant on the continental shelf (0-200 m, Table 1) than on the slope (200-800 m, Table 2). The highest gurnard biomass index $\left(B I_{y}\right)$ was found on the shelves of Malta (GSA $15,112.2 \mathrm{~kg} \mathrm{~km}^{-2}$ ) and the Balearic Islands (GSA 5, $86.4 \mathrm{~kg} \mathrm{~km}^{-2}$ ) during the period 2013-2015 and on the shelves of the eastern Ionian Sea (GSA $20,71.3 \mathrm{~kg}$ $\mathrm{km}^{-2}$ ) during the period 2004-2008. The lowest values appeared on the Italian side of the northern Adriatic (GSA 17a, $3.9 \mathrm{~kg} \mathrm{~km}^{-2}$ ), the Alboran Sea (GSA 1, 6.2 $\mathrm{kg} \mathrm{km}^{-2}$ ) and the west coasts of Italy (GSA 9, $9.5 \mathrm{~kg}$ $\mathrm{km}^{-2}$ and GSA 10, $5.1 \mathrm{~kg} \mathrm{~km}^{-2}$ ) (Table 1).

Table 1. - Mean MEDITS biomass index $\left(B I_{y}: \mathrm{kg} \mathrm{km}^{-2}\right)$ of gurnards (all species pooled) on the continental shelf $(0-200 \mathrm{~m})$ per GSA and year from 1994 to 2015 . The proportional rate of change (\% change) in $B I_{y}$ was calculated between the first and the last three years of the time series in the GSAs where a significant linear trend in $B I_{y}$ was found.

\begin{tabular}{|c|c|c|c|c|c|c|c|c|c|c|c|c|c|c|c|c|c|c|c|c|c|c|c|}
\hline GSA & 94 & 95 & 96 & 97 & 98 & 99 & 00 & 01 & 02 & 03 & 04 & 05 & 06 & 07 & 08 & 09 & 10 & 11 & 12 & 13 & 14 & \multicolumn{2}{|c|}{$15 \begin{array}{c}\% \\
\text { change }\end{array}$} \\
\hline 1 & 2.1 & 4.5 & 2.8 & 2.3 & 7.9 & 8.9 & 3.9 & 5.1 & 3.3 & 1.6 & 8.1 & 5.8 & 28.7 & 21.7 & 6.3 & 7.7 & 0.4 & 10.9 & 2.4 & 2.6 & 10.9 & 5.2 & \\
\hline 5 & & & & & & & & & & & & & & 129.7 & 54.3 & 69.8 & 16.7 & 134.8 & 120.9 & 62.8 & 41.0 & 55.6 & \\
\hline 6 & 9.2 & 17.0 & 6.2 & 7.8 & 16.1 & 9.2 & 13.4 & 13.1 & 4.1 & 5.1 & 8.9 & 10.4 & 15.8 & 18.5 & 4.9 & 12.8 & 14.4 & 23.0 & 9.4 & 18.5 & 17.7 & 18.0 & 66.8 \\
\hline 7 & 79.6 & 146.0 & 101.9 & 42.1 & 43.9 & 80.2 & 59.5 & 69.0 & 70.3 & 54.7 & 41.8 & 39.1 & 54.4 & 55.3 & 72.4 & 65.0 & 49.7 & 40.6 & 53.9 & 77.3 & 28.0 & 27.0 & -59.6 \\
\hline 8 & 6.1 & 39.9 & 46.6 & 62.1 & 23.8 & 50.6 & 25.4 & 29.5 & & 25.6 & 20.4 & 32.2 & 38.1 & 39.2 & 54.5 & 52.2 & 29.9 & 42.6 & 56.2 & 58.3 & 41.1 & 38.9 & \\
\hline 9 & 12.9 & 15.3 & 17.7 & 17.0 & 18.3 & 16.0 & 15.1 & 10.7 & 12.3 & 35.6 & 17.1 & 10.0 & 6.3 & 11.8 & 13.1 & 14.0 & 18.6 & 12.4 & 8.6 & 9.5 & 9.8 & 9.2 & \\
\hline 10 & 11.4 & 16.7 & 15.5 & 8.5 & 17.1 & 11.9 & 14.3 & 14.6 & 12.1 & 15.5 & 4.3 & 9.6 & 9.9 & 13.8 & 4.9 & 13.4 & 11.1 & 12.5 & 12.1 & 6.0 & 7.0 & 2.2 & -65.1 \\
\hline 11 & 39.7 & 28.5 & 35.9 & 34.5 & 39.4 & 65.4 & 26.6 & 85.6 & 38.0 & 60.1 & 33.7 & 57.4 & 45.0 & 86.4 & 24.6 & 43.5 & 40.0 & 43.8 & 47.0 & 17.1 & 15.8 & 29.7 & \\
\hline 15 & & & & & & & & & & & & 45.7 & 88.8 & 83.8 & 127.4 & 95.9 & 51.7 & 97.8 & 75.0 & 75.3 & 66.4 & 94.8 & \\
\hline 16 & 7.9 & 41.2 & 20.4 & 32.6 & 19.0 & 13.3 & 26.7 & 16.8 & 33.7 & 36.4 & 40.6 & 47.1 & 47.5 & 46.0 & 59.3 & 60.1 & 67.3 & 32.1 & 31.3 & 41.6 & 46.9 & 32.5 & 74.0 \\
\hline $17 \mathrm{a}$ & 3.3 & 3.2 & 6.1 & 3.7 & 2.2 & 18.3 & 10.1 & 5.4 & 13.9 & 6.1 & 6.2 & 8.0 & 7.1 & 3.8 & 4.3 & 2.1 & 3.3 & 3.4 & 2.9 & 2.6 & 4.9 & 4.2 & \\
\hline $17 \mathrm{~b}$ & & & 26.2 & 14.0 & 11.7 & & 27.6 & 13.7 & 40.7 & 24.0 & 33.3 & 27.4 & 20.7 & 23.0 & 29.8 & 28.3 & 20.9 & 8.7 & 18.0 & 12.7 & 10.1 & 20.5 & \\
\hline 18 & 2.7 & 3.4 & 2.8 & 2.8 & 3.4 & 19.9 & 8.3 & 19.9 & 6.4 & 8.2 & 10.2 & 26.4 & 10.7 & 10.3 & 13.9 & 17.0 & 21.7 & 15.0 & 22.4 & 9.0 & 8.6 & 1.6 & \\
\hline 19 & 8.5 & 5.0 & 2.5 & 0.6 & 4.4 & 3.0 & 3.7 & 2.9 & 31.0 & 11.9 & 29.8 & 13.4 & 8.7 & 5.8 & 10.9 & 4.5 & 5.3 & 6.6 & 20.4 & 16.4 & 14.1 & 7.2 & \\
\hline 20 & 8.7 & 13.2 & 69.9 & 33.9 & 39.4 & 27.1 & 30.0 & 40.7 & & 45.1 & 48.4 & 14.9 & 65.9 & & 56.0 & & & & & & 21.8 & & \\
\hline 22 & 41.7 & 29.4 & 31.9 & 27.3 & 27.4 & 30.1 & 44.8 & 29.1 & & 60.7 & 43.7 & 51.3 & 30.4 & & 43.6 & & & & & & 30.2 & & \\
\hline 23 & 20.6 & 29.6 & 28.4 & 19.6 & 42.7 & 41.0 & 14.7 & 21.2 & & 54.7 & 22.2 & 23.2 & 15.1 & & 41.1 & & & & & & 15.1 & & \\
\hline 25 & & & & & & & & & & & & 12.3 & 14.4 & 22.0 & 10.7 & 12.0 & 6.5 & 10.4 & 15.7 & 43.3 & & 26.2 & \\
\hline
\end{tabular}


Table 2. - Mean MEDITS biomass index $\left(B I_{y}: \mathrm{kg} \mathrm{km}^{-2}\right)$ of gurnards (all species pooled) on the continental slope (200-800 $\left.\mathrm{m}\right)$ per GSA and year from 1994 to 2015 . The proportional rate of change (\% change) in $B I_{y}$ was calculated between the first and the last three years of the time series in the GSAs where a significant linear trend in $B I_{y}$ was found.

\begin{tabular}{|c|c|c|c|c|c|c|c|c|c|c|c|c|c|c|c|c|c|c|c|c|c|c|c|}
\hline GSA & 94 & 95 & 96 & 97 & 98 & 99 & 00 & 01 & 02 & 03 & 04 & 05 & 06 & 07 & 08 & 09 & 10 & 11 & 12 & 13 & 14 & 15 & $\begin{array}{c}\% \\
\text { change }\end{array}$ \\
\hline 1 & 0.0 & 0.3 & 0.0 & 0.1 & 0.0 & 0.0 & 0.0 & 0.1 & 0.3 & 0.1 & 0.0 & 0.0 & 0.2 & & 0.0 & 0.0 & 0.0 & 0.4 & 0.2 & 0.0 & 0 . & 0.3 & \\
\hline 5 & & & & & & & & & & & & & & 25.9 & 33.3 & 35.4 & 25.5 & 27.6 & 23.9 & 29.7 & 16.3 & 15.4 & -35.1 \\
\hline 6 & 0.2 & 0.5 & 1.1 & 0.5 & 0.2 & 0.0 & 6.9 & 3.5 & 1.0 & 0.3 & 0.7 & 1.4 & 4.8 & 2.9 & 1.7 & 3.4 & 0.6 & 5.1 & 1.8 & 1.4 & 1.9 & 5.0 & \\
\hline 7 & 8.0 & 58.5 & 44.8 & 30.8 & 27.5 & 62.8 & 63.4 & 44.3 & 26.4 & 51.8 & 39.3 & 44.4 & 27.0 & 31.4 & 32.0 & 67.1 & 46.8 & 57.3 & 50.1 & 19.6 & 55.4 & 62.3 & \\
\hline 8 & 38.1 & 41.9 & 37.7 & 26.9 & 37.1 & 32.6 & 10.7 & 37.1 & & 20.3 & 32.4 & 28.3 & 48.6 & 47.3 & 26.0 & 19.2 & 23.9 & 23.5 & 13.5 & 16.5 & 25.6 & 21.2 & -46.3 \\
\hline 9 & 0.9 & 2.0 & 1.4 & 1.1 & 0.9 & 0.3 & 1.1 & 0.6 & 1.0 & 1.1 & 1.8 & 1.1 & 1.2 & 0.7 & 0.8 & 6.3 & 1.8 & 1.2 & 4.2 & 4.2 & 2.3 & 1.8 & 88.0 \\
\hline 10 & 0.7 & 1.2 & 1.8 & 1.7 & 4.8 & 1.5 & 3.5 & 0.8 & 1.5 & 3.1 & 3.0 & 6.0 & 4.4 & 2.0 & 4.4 & 4.9 & 5.4 & 3.2 & 3.7 & 5.1 & 2 & 1.5 & 136.0 \\
\hline 11 & 12.2 & 9.5 & 33.0 & 14.8 & 19.6 & 10.5 & 10.2 & 22.8 & 28.4 & 10.3 & 4.5 & 14.3 & 2.3 & 12.5 & 3.2 & 7.3 & 4.6 & 6.2 & 8.9 & 4.4 & 1.8 & 9.7 & -63.9 \\
\hline 15 & & & & & & & & & & & & 58.6 & 27.3 & 1.3 & 40.3 & 36.8 & 36.5 & 65.7 & 49.9 & 24.3 & 23.9 & 36.7 & \\
\hline 16 & 6.0 & 1.3 & 4.8 & 0.4 & 1.3 & 0.7 & 0.4 & 2.1 & 4.0 & 9.8 & 2.1 & 6.9 & 6.1 & 10.7 & 16.8 & 24.5 & 4.7 & 5.8 & 5.9 & 4.1 & 1.1 & 4.7 & \\
\hline 17 & 0.0 & 0.1 & 2.4 & 2.0 & 3.7 & 13.3 & 3.9 & 0.4 & 21.1 & 13.0 & 5.8 & 0.9 & 1.2 & 2. & 3.9 & 1.1 & 4.4 & 0. & 0.1 & 1. & 8 & 2.0 & \\
\hline $17 \mathrm{~b}$ & & & 2.2 & 11.3 & 1.1 & & 112.4 & 20.8 & 1.7 & 1.4 & 0.6 & 1.6 & 5.7 & 3.2 & 0.0 & 0.4 & 15.1 & 0.3 & 5.9 & 1.4 & 6.1 & 4.7 & \\
\hline 18 & 5.7 & 6.6 & 9.5 & 1.2 & 0.9 & 29.5 & 4.8 & 4.1 & 14.6 & 3.4 & 14.1 & 7.3 & 2.6 & 15.7 & 8.5 & 12.3 & 2.7 & 2.1 & 5.1 & 2.7 & 4.2 & 2.9 & \\
\hline 19 & 0.0 & 0.1 & 0.2 & 0.3 & 0.0 & 0.1 & 0.3 & 0.9 & 0.2 & 0.5 & 0.7 & 0.2 & 0.9 & 0.7 & 0.2 & 0.3 & 0.4 & 2.2 & 0.4 & 1.8 & 0.4 & 0.9 & 875.6 \\
\hline 20 & 12.6 & 0.0 & 8.1 & 1.1 & 7.8 & 25.0 & 14.7 & 24.4 & & 52.1 & 39.6 & 39.0 & 34.0 & & 41.8 & & & & & & 15.2 & & 448.3 \\
\hline 22 & 6.7 & 8.5 & 10.2 & 8.1 & 14.3 & 21.9 & 17.9 & 9.7 & & 28.9 & 25.8 & 19.8 & 16.0 & & 29.9 & & & & & & 8.1 & & \\
\hline 23 & 8.9 & 0.4 & 14.0 & 13.8 & 24.7 & 28.8 & 16.9 & 28.7 & & 40.5 & 31.0 & 27.5 & 18.1 & & 14.8 & & & & & & 9.2 & & \\
\hline 25 & & & & & & & & & & & & 17.0 & 33.9 & 19.0 & 11.3 & 21.5 & 14.7 & 9.7 & 14.3 & 8.7 & & 30.1 & \\
\hline
\end{tabular}

The shelf areas where a significant negative linear trend in $B I_{y}$ was found were the Gulf of Lions (GSAs $\left.7, \mathrm{r}^{2}=0.27, \mathrm{p}<0.01\right)$ and the southern Tyrrhenian Sea $\left(\mathrm{r}^{2}=0.28, \mathrm{p}<0.01\right)$ while the trend was positive in northern Spain (GSAs 6, $\left.\mathrm{r}^{2}=0.30, \mathrm{p}<0.05\right)$ and south of Sicily (GSA 16, $\mathrm{r}^{2}=0.30, \mathrm{p}<0.01$ ) (Fig. 4A).

The highest mean $B I_{y}$ values of gurnards on the continental slope in the last three years of the time series were found in the Gulf of Lions $(45.8 \mathrm{~kg}$ $\left.\mathrm{km}^{-2}\right)$, Maltese waters $\left(28.3 \mathrm{~kg} \mathrm{~km}^{-2}\right)$ and the eastern Ionian Sea (38.6 kg km-2 in 2004-2008). For the same period, the lowest relative biomass $\left(B I_{y}<3.0\right.$ $\mathrm{kg} \mathrm{km}^{-2}$ ) occurred in the Alboran, western Ionian, northern Tyrrhenian and Ligurian seas, as well as on the Italian side of GSA 17. Gurnard $B I_{y}$ increased linearly over time in the Tyrrhenian and Ligurian seas [GSA $9\left(\mathrm{r}^{2}=0.19, \mathrm{p}<0.05\right)$ and GSA $10\left(\mathrm{r}^{2}=0.14\right.$, $\mathrm{p}<0.05]$ and in the Ionian Sea [GSA $19\left(\mathrm{r}^{2}=0.27\right.$, $\mathrm{p}<0.01)$ and GSA $20\left(\mathrm{r}^{2}=0.26, \mathrm{p}<0.05\right]$. A linear decrease occurred in the Balearic Islands $\left(r^{2}=0.44\right.$, $\mathrm{p}<0.05)$, eastern Corsica $\left(\mathrm{r}^{2}=0.18, \mathrm{p}<0.05\right)$ and Sardinia $\left(r^{2}=0.29, p<0.05\right)$ (Fig. 4B).
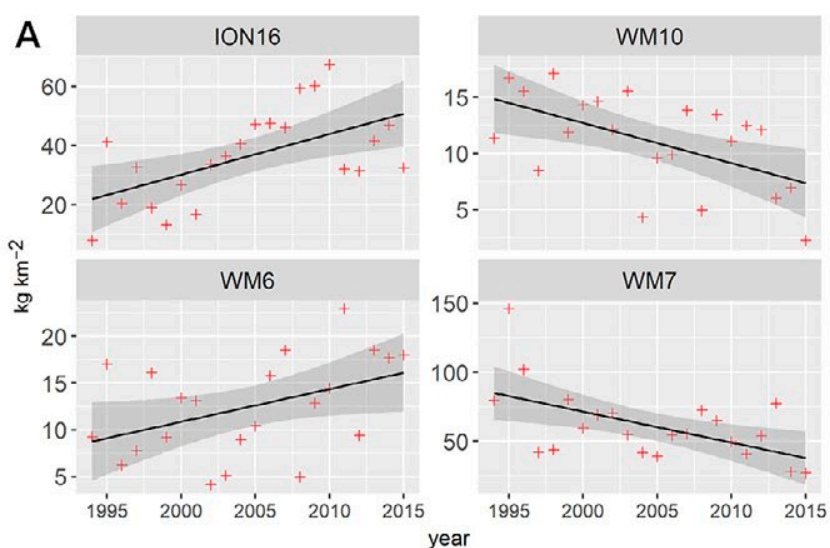

\section{Temporal trends in species abundance}

\section{Lepidotrigla cavillone}

The large-scaled gurnard was mostly distributed on the outer shelf between 36 and $187 \mathrm{~m}$ depth. It displayed an almost linear decrease in relative biomass in the western Mediterranean $\left(\mathrm{r}^{2}=0.38, \mathrm{p}<0.01\right)$ and in the Aegean ecoregion $\left(r^{2}=0.49, p<0.01\right)$, while it increased in the Ionian ecoregion $\left(\mathrm{r}^{2}=0.27, \mathrm{p}<0.01\right)$ (Fig. 5).

At the GSA level a positive linear trend was found in the south of Sicily $\left(\mathrm{r}^{2}=0.27, \mathrm{p}<0.01\right)$, where there was a $224 \%$ increase in $B I_{y}$ in 2013-2015 compared with the beginning of MEDITS, and in eastern Corsica (GSA 8, $\left.+109 \%: \mathrm{r}^{2}=0.22, \mathrm{p}<0.05\right)$. The trend was significantly decreasing in the Gulf of Lions $\left(-69 \%: \mathrm{r}^{2}=0.48, \mathrm{p}<0.01\right)$, in the southern Tyrrhenian $\left(-75 \% ; \mathrm{r}^{2}=0.17, \mathrm{p}<0.05\right)$ and northwestern Adriatic seas $\left(-63 \%: \mathrm{r}^{2}=0.18, \mathrm{p}<0.05\right)$ (Fig. 5B; Appendix 1). During the period 2013-2015 the highest relative species abundances occurred in Cyprus $\left(26.7 \mathrm{~kg} \mathrm{~km}^{-2}\right)$, Maltese waters $\left(26.2 \mathrm{~kg} \mathrm{~km}^{-2}\right)$ and eastern Corsica (GSA 8: $23.0 \mathrm{~kg} \mathrm{~km}^{-2}$ ). High $B I_{y}$ was also found in the eastern Ionian Sea $\left(36 \mathrm{~kg} \mathrm{~km}^{-2}\right)$ during the

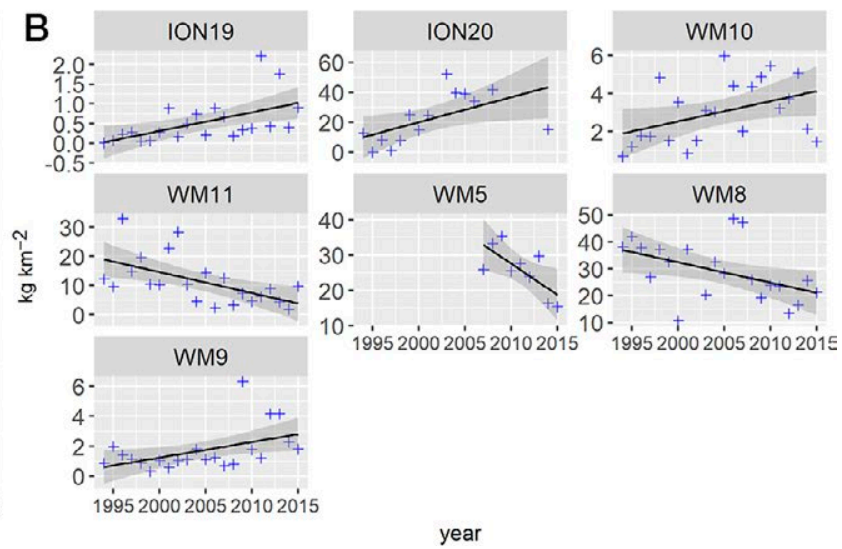

Fig. 4. - All gurnards pooled. GSAs showing a significant linear temporal trend in MEDITS relative biomass index $\left(\mathrm{kg} \mathrm{km}^{-2}\right)$ on the continental shelf (A, 0-200 m) and slope (B, 200-800 m). GSA codes: 10, southern and central Tyrrhenian Sea; 16, south of Sicily; 6, northern Spain; 7, Gulf of Lions; 11, Sardinia; 19, western Ionian Sea; 20, eastern Ionian Sea; 5, Balearic Island; 8, Corsica; 9, Ligurian Sea and northern Tyrrhenian Sea. 

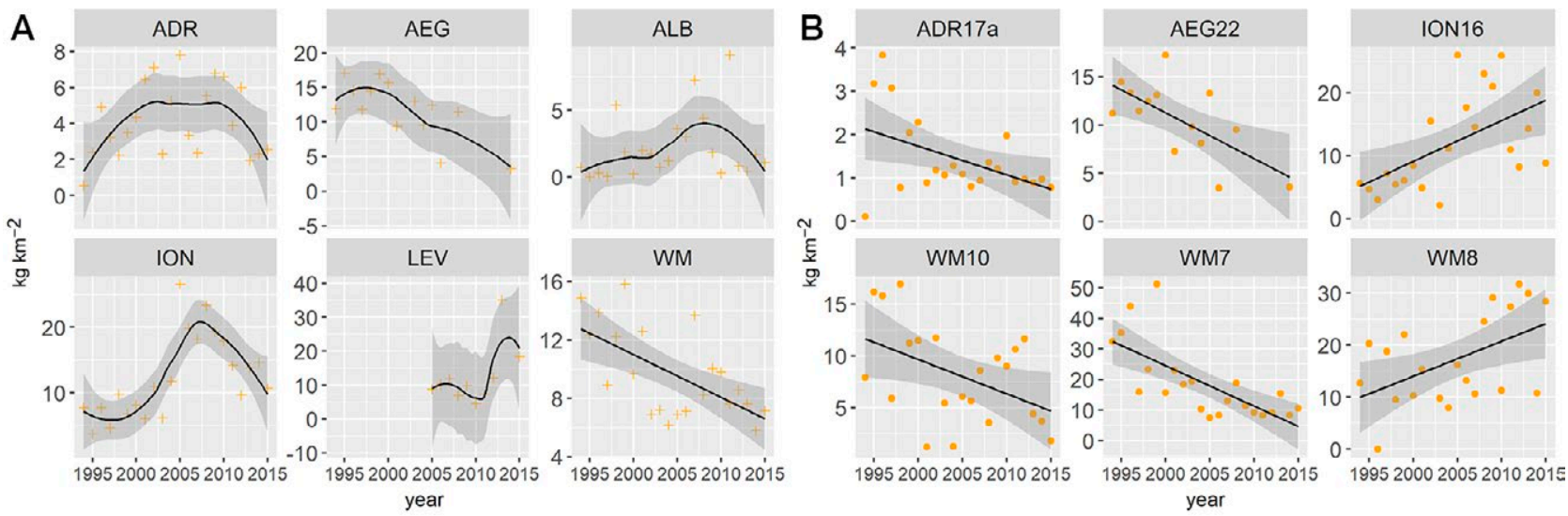

Fig. 5. - Lepidotrigla cavillone. Mean and 95\% confidence intervals of the MEDITS relative biomass index $\left(\mathrm{kg} \mathrm{km}^{-2}\right)$ in the Mediterranean ecoregions (A) and geographical sub-areas (GSAs, B) where a significant linear trend was found. GSA codes: 10, southern and central Tyrrhenian Sea; 16, south of Sicily; 17a, NW Adriatic Sea; 22, Aegean Sea; 7, Gulf of Lions; 8, eastern Corsica.
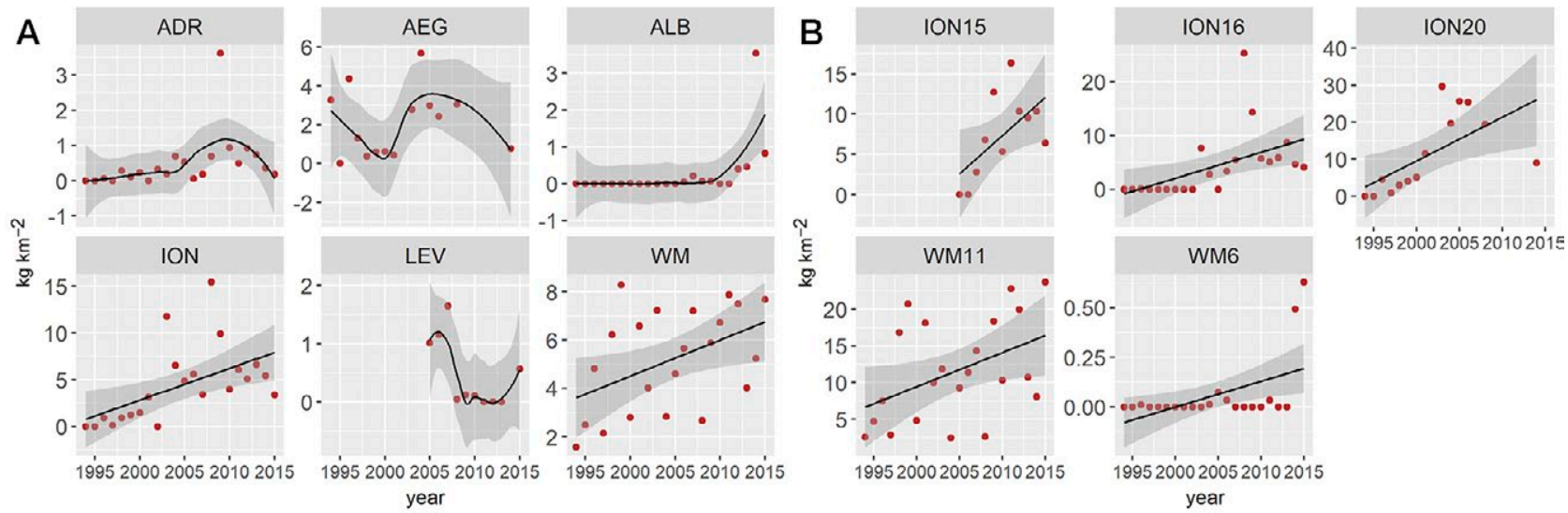

Fig. 6. - Lepidotrigla dieuzeidei. Mean and 95\% confidence intervals of the MEDITS relative biomass index $\left(\mathrm{kg} \mathrm{km}^{-2}\right)$ in the Mediterranean ecoregions (A) and geographical sub-areas (GSAs, B) where a significant linear trend was found. GSA codes: 11, Sardinia; 15, Malta; 16, south of Sicily; 20, eastern Ionian Sea; 6, northern Spain.

period 2004-2008 (Appendix 1). By contrast, very low abundances $\left(B I_{y}<1.5 \mathrm{~kg} \mathrm{~km}^{-2}\right)$ were found in the western sector of the Adriatic Sea and in the western Ionian and Alboran seas.

\section{Lepidotrigla dieuzeidei}

The bulk of the MEDITS catch of spiny gurnard was obtained at depths ranging from 70 to $360 \mathrm{~m}$, with the highest abundances in 2013-2015 found in eastern Corsica $\left(25.7 \mathrm{~kg} \mathrm{~km}^{-2}\right)$, Sardinia $\left(14.2 \mathrm{~kg} \mathrm{~km}^{-2}\right)$, the Balearic Islands $\left(10.0 \mathrm{~kg} \mathrm{~km}^{-2}\right)$, the eastern Ionian Sea $\left(9.0 \mathrm{~kg} \mathrm{~km}^{-2}\right)$ and Malta $\left(8.8 \mathrm{~kg} \mathrm{~km}^{-2}\right.$, Appendix 2). The species showed a significant increasing trend in the western Mediterranean $\left(r^{2}=0.21, p<0.05\right)$ and Ionian ecoregions $\left(r^{2}=0.25, p<0.05\right)$ during the study period (Fig. 6A). A significant linear trend was found in Sardinia $\left(r^{2}=0.15, p<0.05\right)$, the Ionian GSAs $15\left(r^{2}=0.30\right.$, $\mathrm{p}<0.05), 16\left(\mathrm{r}^{2}=0.23, \mathrm{p}<0.05\right)$ and $20\left(\mathrm{r}^{2}=0.34, \mathrm{p}<0.05\right)$ and northernern Spain $\left(\mathrm{r}^{2}=0.22, \mathrm{p}<0.05\right)$ (Fig. 6B). The species was absent from GSAs 19 and 23, with records also lacking in several other GSAs, especially during the first MEDITS period (1994-2000, Appendix 2), possibly due to misidentifications and confusion with the congeneric L. cavillone.

\section{Lepidotrigla spp.}

Appendix 3 shows the abundances and trends in the relative biomass of the two Lepidotrigla species combined for the 26-360 m depth range, where more than $90 \%$ of the positive hauls for the two species were found. The resulting pattern is not very different from the one observed for the large-scaled gurnard, which was more abundant than the spiny gurnard in most of the GSAs. The main differences were a significant increase in the Alboran Sea (+918\% in $\left.B I_{y}\right)$, mostly due to the occurrence of the spiny gurnard in the catch of the last three years, and a decrease in the Aegean Sea $\left(-55.1 \%\right.$ in $\left.B I_{y}\right)$.

\section{Chelidonichtys cuculus}

Red gurnard was mostly distributed between 60 and $270 \mathrm{~m}$, where it achieved the highest relative abundance in the period 2013-2015 in the Balearic Islands $\left(43.8 \mathrm{~kg} \mathrm{~km}^{-2}\right)$, south of Sicily $\left(19.8 \mathrm{~kg} \mathrm{~km}^{-}\right.$ ${ }^{2}$ ), Malta $\left(13.2 \mathrm{~kg} \mathrm{~km}^{-2}\right)$ and the Aegean Sea (GSA 22: $11.5 \mathrm{~kg} \mathrm{~km}^{-2}$, Appendix 4). A positive trend $\left(\mathrm{r}^{2}=0.46, \mathrm{p}<0.01\right)$ was found in the Ionian ecoregion, with a strong increasing trend in the western Ionian Seas $\left(+1039 \%, \mathrm{r}^{2}=0.34, \mathrm{p}<0.01\right)$ (Fig. 7A 

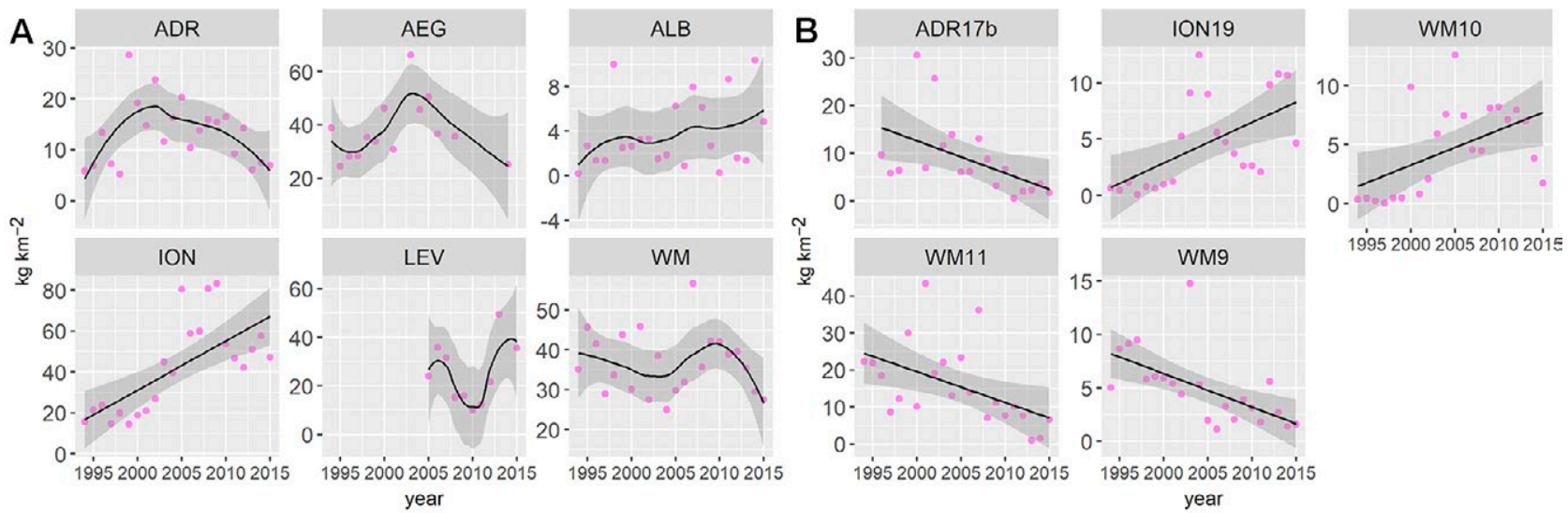

Fig. 7. - Chelidonichthys cuculus. Mean and 95\% confidence intervals of the MEDITS relative biomass index $\left(\mathrm{kg} \mathrm{km}^{-2}\right)$ in the Mediterranean ecoregions (A) and geographical sub-areas (GSAs, B) where a significant linear trend was found. GSA codes: 10, southern and central Tyrrhenian Sea; 11, Sardinia; 17b, NE Adriatic Sea; 19, western Ionian Sea; 9, Ligurian Sea and northern Tyrrhenian Sea.

and Appendix 4). In the western Mediterranean, the $B I_{y}$ fluctuated from 1994 with a contrasted spatial pattern: a sharply increasing trend in the southern Tyrrhenian $\left(+1102 \%, \mathrm{r}^{2}=0.22, \mathrm{p}<0.05\right)$ and a decreasing trend in the northern Tyrrhenian and Ligurian Seas $\left(-75.0 \%, \mathrm{r}^{2}=0.34, \mathrm{p}<0.01\right)$ and in Sardinia $\left(-85 \%, \mathrm{r}^{2}=0.21, \mathrm{p}<0.05\right)$ (Fig. 7). In the Adriatic Sea the species was much more abundant on the east side, where, however, it declined significantly from the 1990s $\left(-73.7 \%, \mathrm{r}^{2}=0.21, \mathrm{p}<0.05\right)$ (Fig. 7B, Appendix 4).

\section{Chelidonichthys obscurus}

The longfin gurnard is a shelf species, mostly occurring between 20 and $120 \mathrm{~m}$ depth. It was absent in the Adriatic and Levantine ecoregions, occurring sporadically at a very low relative biomass in the Aegean Sea (Fig. 8A). The temporal trend showed a significant decrease in the western Mediterranean $\left(r^{2}=0.21\right.$, $\mathrm{p}<0.05$, Fig. $8 \mathrm{~A}$ ) where a linear reduction appeared in GSAs $6\left(-88 \%: \mathrm{r}^{2}=0.13, \mathrm{p}<0.05\right)$ and $7(-96 \%$, $\mathrm{r}^{2}=0.21, \mathrm{p}<0.05$, Fig. 8B). The highest recent (20132015) $B I_{y}$ was found in southern Sicily $\left(1.3 \mathrm{~kg} \mathrm{~km}^{-2}\right)$, where, however, the species abundance decreased linearly $\left(\mathrm{r}^{2}=0.14, \mathrm{p}<0.05\right)$, and in Sardinia $\left(0.9 \mathrm{~kg} \mathrm{~km}^{-2}\right)$
(Fig. 8B, Appendix 5). The only area where the species increased linearly through time was the eastern Ionian Sea $\left(r^{2}=0.23, p<0.05\right.$, Fig. 8B).

\section{Eutrigla gurnardus}

The grey gurnard was more abundant on the continental shelf (30-165 m) of the western Mediterranean region and particularly in the Gulf of Lions. In this area the species was several times more abundant $\left(19.4 \mathrm{~kg} \mathrm{~km}^{-2}\right)$ than elsewhere. In the other ecoregions (Fig. 9A), it was found at a very low relative abundance and it was absent from the Alboran and southern Tyrrhenian seas, Crete and Cyprus (Fig. 9B and Appendix 6). A significant and positive linear trend in $B I_{y}$ was found in the Ionian region $\left(\mathrm{r}^{2}=0.48, \mathrm{p}<0.01\right)$ and specifically in Malta $(+58.8 \%$, $\left.\mathrm{r}^{2}=0.21, \mathrm{p}<0.05\right)$ and south of Sicily $(+11000 \%$, $r^{2}=0.34, p<0.01$, Fig. 9B).

\section{Chelidonichthys lucerna}

The tub gurnard is also a shelf species, mainly distributed between 15 and $175 \mathrm{~m}$ depth. It was significantly decreasing on the continental shelf of the western Mediterranean $\left(\mathrm{r}^{2}=0.48, \mathrm{p}<0.01\right)$ and specifi-
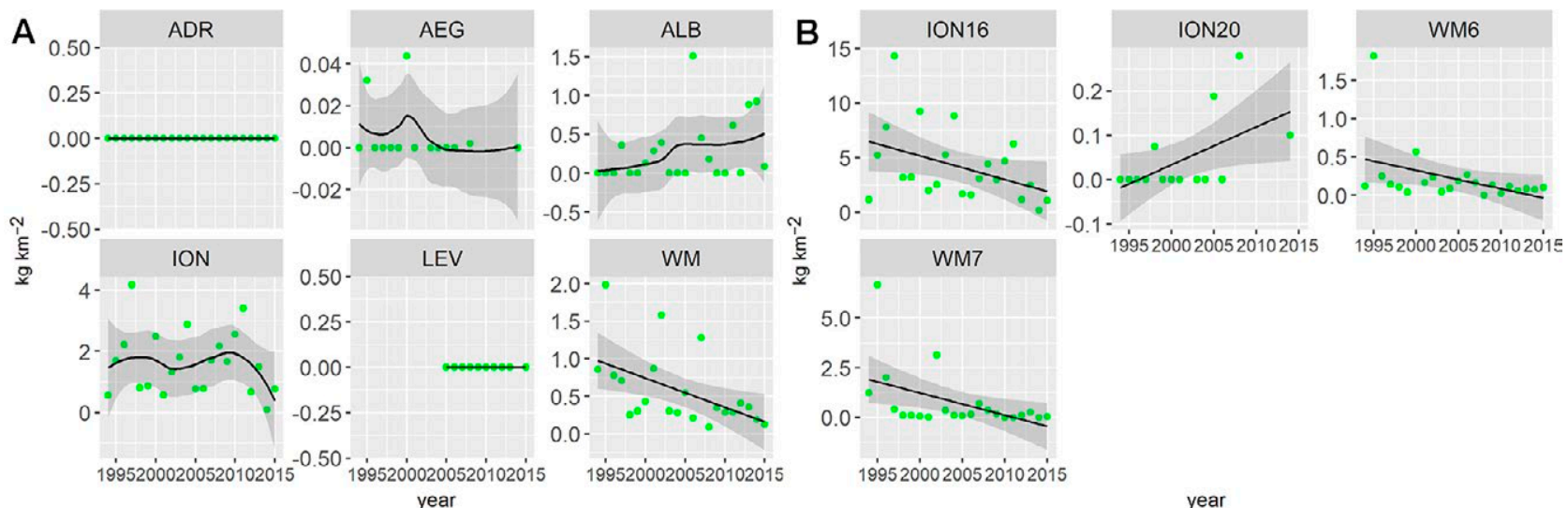

Fig. 8. - Chelidonichthys obscurus. Mean and 95\% confidence intervals of the MEDITS relative biomass index $\left(\mathrm{kg} \mathrm{km}^{-2}\right)$ in the Mediterranean ecoregions (A) and geographical sub-areas (GSAs, B) where a significant linear trend was found. GSA codes: 16, south of Sicily; 20, eastern Ionian Sea; 6, northern Spain; 7, Gulf of Lions. 

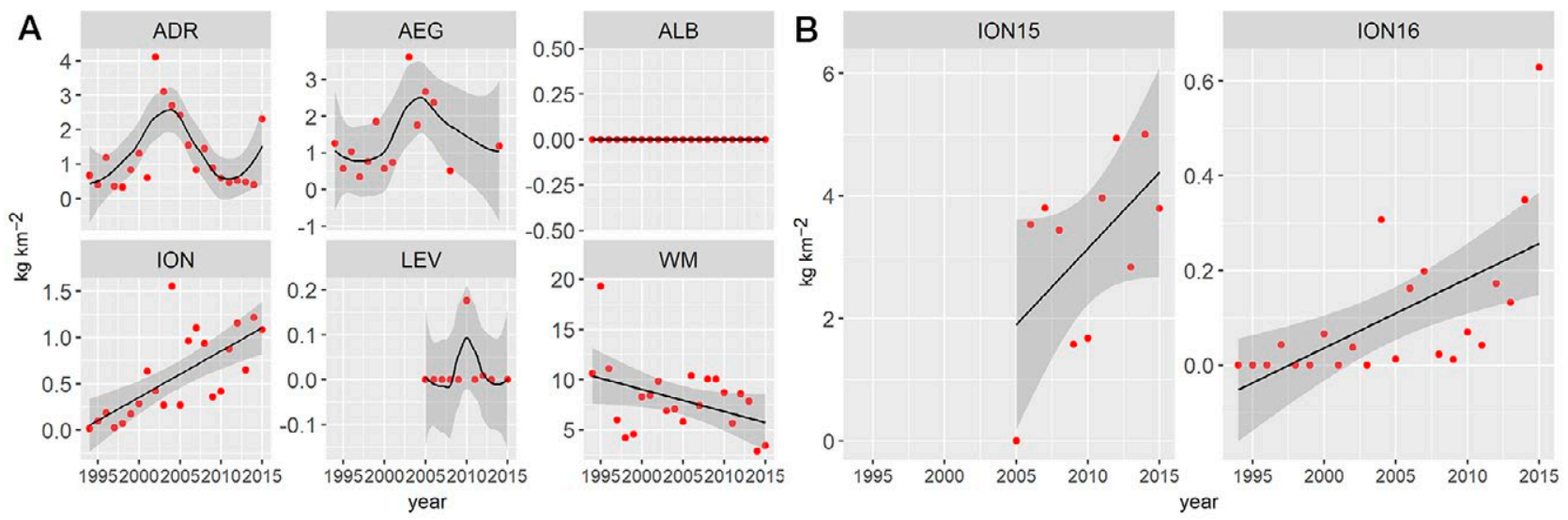

Fig. 9. - Eutrigla gurnardus. Mean and 95\% confidence intervals of the MEDITS relative biomass index $\left(\mathrm{kg} \mathrm{km}^{-2}\right)$ in the Mediterranean ecoregions (A) and geographical sub-areas (GSAs, B) where a significant linear trend was found. GSA codes: 15, Malta, 16, south of Sicily.
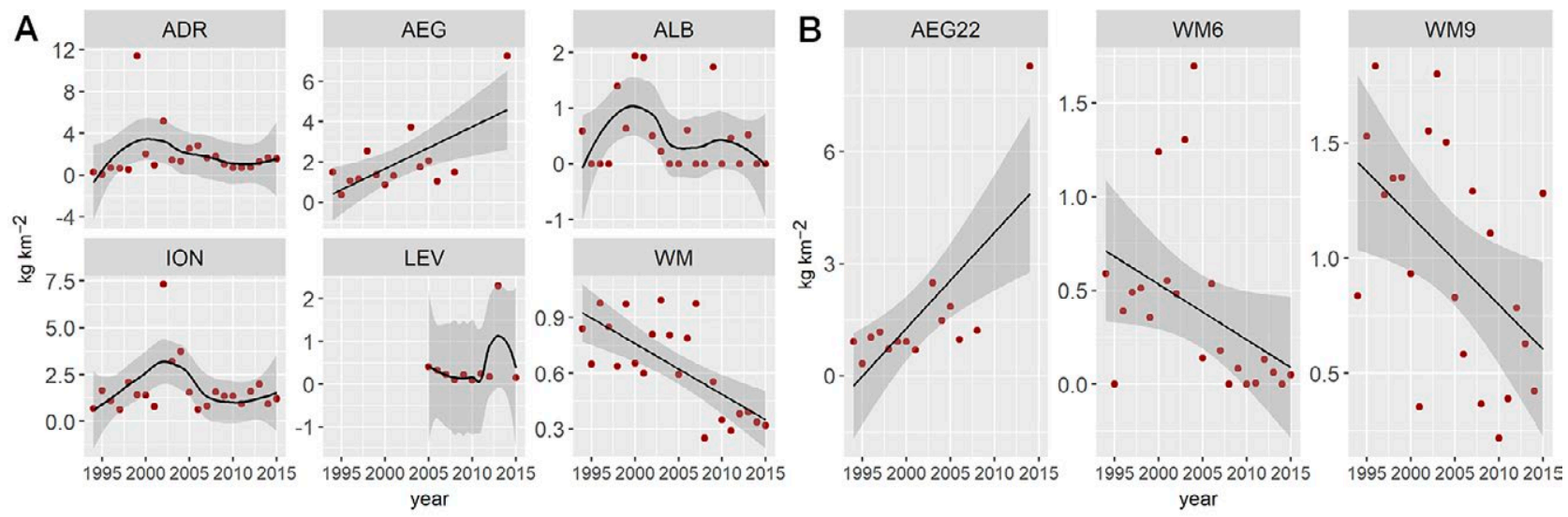

Fig. 10. - Chelidonichthys lucerna. Mean and 95\% confidence intervals of the MEDITS relative biomass index $\left(\mathrm{kg} \mathrm{km}^{-2}\right)$ in the Mediterranean ecoregions (A) and geographical sub-areas (GSAs, B) where a significant linear trend was found. GSA codes: 22, Aegean Sea; 6, northern Spain; 9, Ligurian Sea and northern Tyrrhenian Sea.

cally in the GSAs $6\left(r^{2}=0.13, p<0.05\right)$ and $9\left(r^{2}=0.22\right.$, $\mathrm{p}<0.05)$, while an increasing trend was observed in the GSA 22, in the Aegean Sea $\left(r^{2}=0.41, p<0.01\right)$ (Fig. 10). In the other regions the species fluctuated at low abundance levels without any clear temporal trend (Appendix 7). In 2013-2015 the highest $B I_{y}$ was obtained on the continental shelf of the Aegean Sea $\left(8.3 \mathrm{~kg} \mathrm{~km}^{-2}\right.$ in 2014) and the western Ionian Sea (GSA 19: $2.8 \mathrm{~kg} \mathrm{~km}^{-2}$, Appendix 7).

\section{Trigla lyra}

The piper gurnard is typically distributed on the continental slope, with the highest $B I_{y}$ values found in the Gulf of Lions $\left(33.6 \mathrm{~kg} \mathrm{~km}^{-2}\right)$, Malta $\left(31.1 \mathrm{~km}^{-2}\right)$ and Balearic waters $\left(23.3 \mathrm{~kg} \mathrm{~km}^{-2}\right)$ during the period 2013-2015 (Appendix 8). The species showed an increasing trend in the western Mediterranean $\left(\mathrm{r}^{2}=0.49\right.$, $\mathrm{p}<0.01)$ and Ionian $\left(\mathrm{r}^{2}=0.50, \mathrm{p}<0.01\right)$ ecoregions (Fig. 11A). In the first area, $B I_{y}$ values increased in the northern Tyrrhenian and Ligurian seas $\left(r^{2}=0.13\right.$, $\mathrm{p}<0.05)$, while they decreased in eastern Corsica $\left(r^{2}=0.26, p<0.01\right)$. In the Ionian area the species increased in the Strait of Sicily in GSAs $15\left(r^{2}=0.25\right.$, $\mathrm{p}<0.05)$ and $16\left(\mathrm{r}^{2}=0.17, \mathrm{p}<0.05\right)$, and in the western Ionian Sea $\left(r^{2}=0.17, p<0.05\right.$, Fig. 11B $)$.

\section{Chelidonichthys lastoviza}

The streaked gurnard was mostly caught between 25 and $120 \mathrm{~m}$ depth, with the highest $B I_{y}$ found in Malta $\left(59.3 \mathrm{~kg} \mathrm{~km}^{-2}\right)$ and the Balearic Island $(34.5 \mathrm{~kg}$ $\mathrm{km}^{-2}$ ) in 2013-2015. The species was also abundant in the Aegean Sea in GSA 22 (Appendix 9). It showed an increasing trend in the western Mediterranean $\left(\mathrm{r}^{2}=0.29\right.$, $\mathrm{p}<0.05)$ and the Ionian ecoregions $\left(\mathrm{r}^{2}=0.18, \mathrm{p}<0.05\right.$, Fig. 12A). The species showed wide temporal fluctuations in $B I_{y}$, with significant positive linear trends in GSAs $6\left(\mathrm{r}^{2}=0.29, \mathrm{p}<0.01\right)$ and $23\left(\mathrm{r}^{2}=0.60, \mathrm{p}<0.01\right)$. A negative trend was found in GSAs $7\left(\mathrm{r}^{2}=0.29, \mathrm{p}<0.01\right)$, $10\left(\mathrm{r}^{2}=0.45, \mathrm{p}<0.01\right)$ and $16\left(\mathrm{r}^{2}=0.23, \mathrm{p}<0.05\right)$, and on both the west $\left(r^{2}=0.25, p<0.01\right)$ and east side $\left(r^{2}=0.21\right.$, $\mathrm{p}<0.01)$ of the northern Adriatic Sea (Fig. 12B).

\section{Peristedion cataphractum}

The African armoured searobin was mostly present on the continental slope below $200 \mathrm{~m}$, with $90 \%$ of the positive hauls being found between 115 and 550 $\mathrm{m}$ depth. It reached by far the highest $B I_{y}$ in Maltese waters $\left(27.3 \mathrm{~kg} \mathrm{~km}^{-2}\right.$ in 2013-2015), being generally more than ten times less abundant in all the other GSAs except GSA 20 in 1994-98 (12.2 kg km², Appendix 

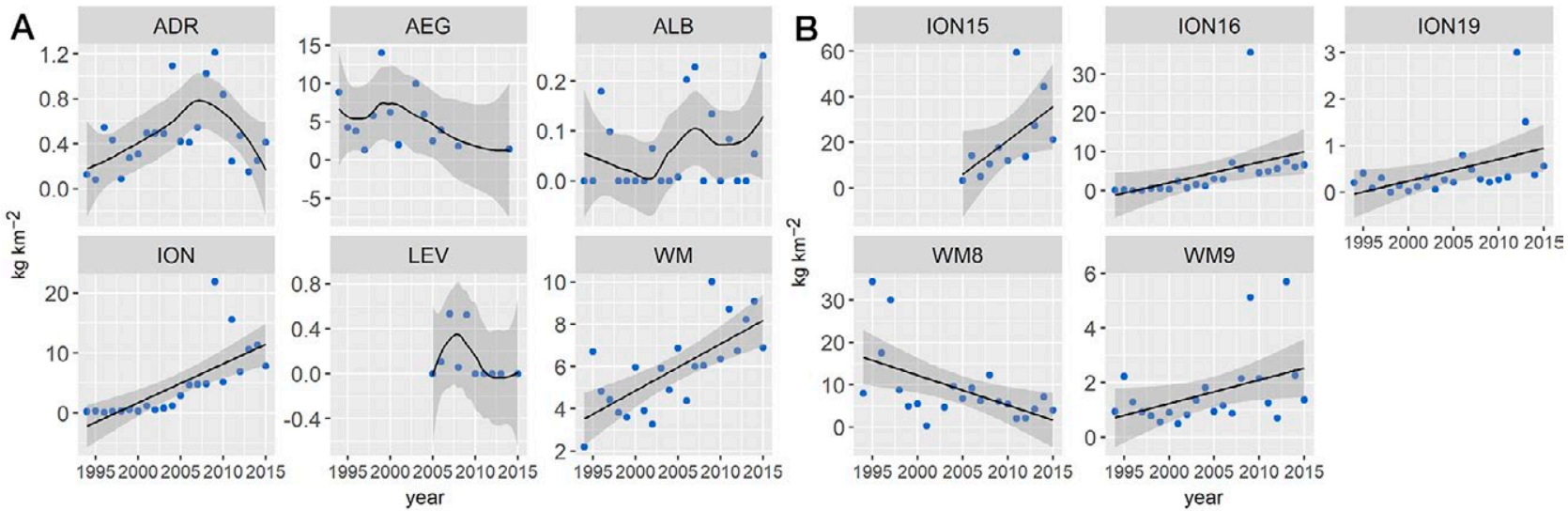

Fig. 11. - Trigla lyra. Mean and 95\% confidence intervals of the MEDITS relative biomass index $\left(\mathrm{kg} \mathrm{km}^{-2}\right)$ in the Mediterranean ecoregions (A) and geographical sub-areas (GSAs, B) where a significant linear trend was found. GSA codes: 15, Malta; 16, south of Sicily; 19, western Ionian Sea; 8, eastern Corsica; 9, Ligurian Sea and northern Tyrrhenian Sea.
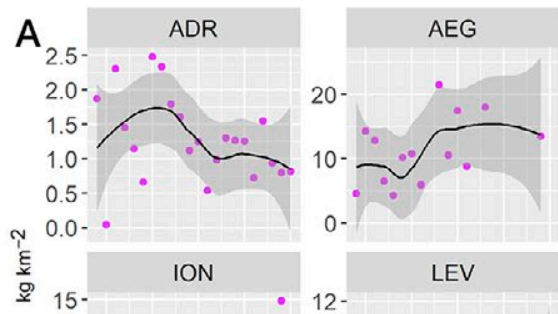

LEV

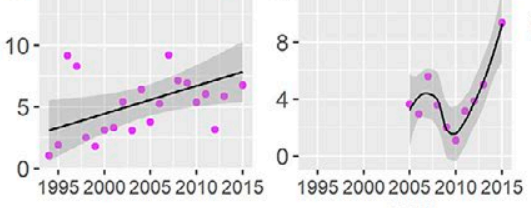

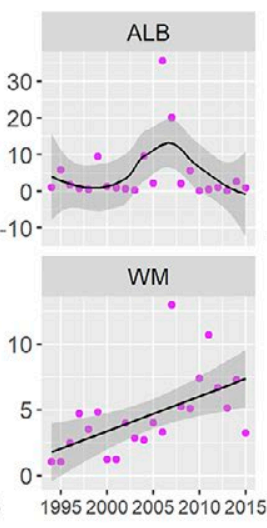

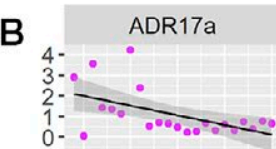

ION16
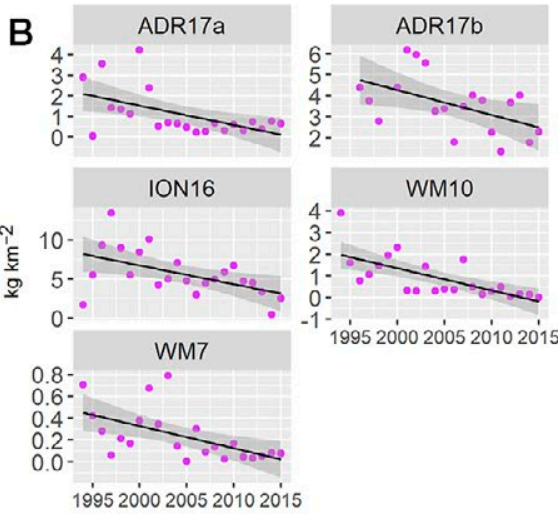

190520002010520

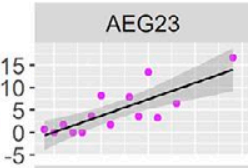

WM6

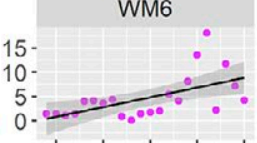

19952000200520102015

Fig 12 - Chelidonichthys lastoviza. Mean and 95\% confidence intervals of the MEDITS relative biomass index ( $\left.\mathrm{kg} \mathrm{km}^{-2}\right)$ in the Mediterranean ecoregions (A) and geographical sub-areas (GSAs, B) where a significant linear trend was found. GSA codes: 10, southern and central Tyrrhenian Sea; 16, south of Sicily; 17a, NW Adriatic Sea; 17b, NE Adriatic Sea; 23, Crete; 6, northern Spain; 7, Gulf of Lions.

10). The species showed a linear increasing trend in the Adriatic $\left(\mathrm{r}^{2}=0.69, \mathrm{p}<0.01\right)$, Ionian $\left(\mathrm{r}^{2}=0.48, \mathrm{p}<0.01\right)$ and Levantine $\left(\mathrm{r}^{2}=0.35, \mathrm{p}<0.05\right)$ ecoregions and a decreasing trend in the western Mediterranean $\left(r^{2}=0.47\right.$, $\mathrm{p}<0.01$, Fig. 13A). A positive trend was found in the Adriatic (GSA 17a: $\mathrm{r}^{2}=0.20, \mathrm{p}<0.05$ and 18: $\mathrm{r}^{2}=0.77$, $\mathrm{p}<0.01)$, south of Sicily $\left(\mathrm{r}^{2}=0.16, \mathrm{p}<0.05\right)$ and the western Ionian Sea $\left(r^{2}=0.16, p<0.05\right)$, while a significant linear decrease was observed in Sardinia $\left(r^{2}=0.46\right.$, $\mathrm{p}<0.01$, Fig. 13B).

\section{DISCUSSION}

This study provides an overview of the status of gurnards in the northern Mediterranean Sea using 22 years of MEDITS bottom trawl survey data. Gurnards
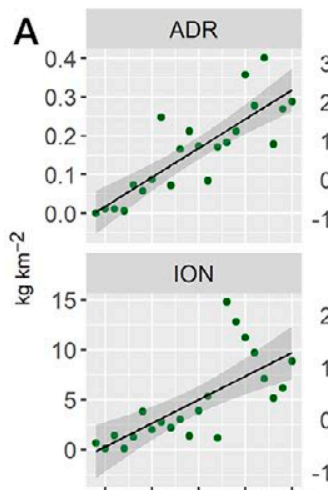

$19 \dot{9} 20002005200^{\prime} 1020^{\prime}$

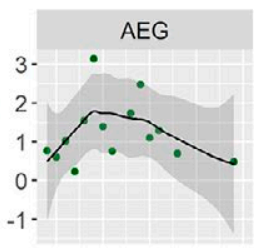

LEV

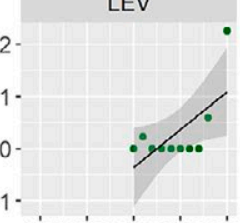

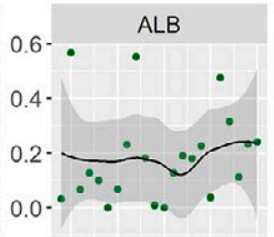

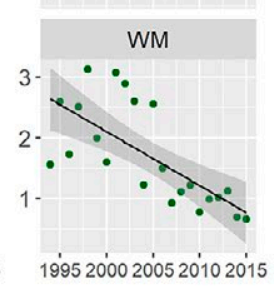

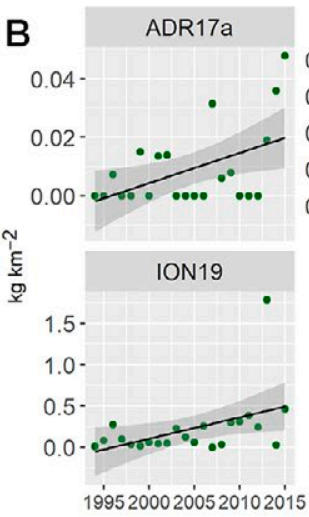

19952000200520102015
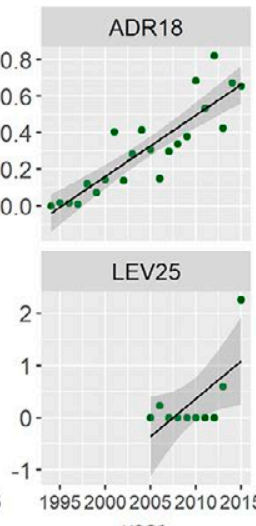

year

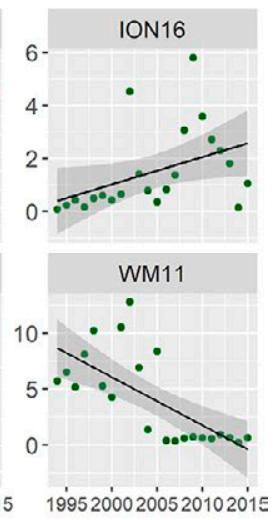

$19 \dot{9} 5200020052010201$ 1

Fig. 13. - Peristedion cataphractum. Mean and 95\% confidence intervals of the MEDITS relative biomass index (kg km $\left.{ }^{-2}\right)$ in the Mediterranean ecoregions (A) and geographical sub-areas (GSAs, B) where a significant linear trend was found. GSA codes: 11, Sardinia; 16, south of Sicily; 17a, NW Adriatic Sea; 18, southern Adriatic Sea; 19, western Ionian Sea; 25, Cyprus. 
are an important component of demersal assemblages in Mediterranean ecoregions, inhabiting soft and detrital bottoms from the shallower portion of the continental shelf to the upper slope. Some of them, such as C. lucerna, T. lyra, C. cuculus, C. lastoviza and E. gurnardus, can be important commercial species for the demersal fisheries. The other species mainly constitute commercial or non-commercial trawling by-catch. Results of our study highlighted important differences among Mediterranean ecoregions and sub-areas (GSAs) in terms of species composition and dominance, which are probably related to the different biogeographic affinity of the species. The majority of the Mediterranean gurnards have a sub-tropical affinity, with only C. cuculus, C. obscurus and E. gurnardus being temperate species (http://www.fishbase.org). In particular, the Ionian and western Mediterranean ecoregions appeared very similar in the structure of the gurnard species guild, with $C$. cuculus being the most abundant species, followed by five others (L. cavillone, L. dieuzeidei, T. lyra, C. lastoviza, P. cataphractum or E. gurnardus) with a similar level of abundance, together accounting for more than $90 \%$ of the relative biomass for the examined period. An opposite pattern was observed in the Levantine Sea, where only data for Cyprus are available. Here the k-dominance curve is steep with three species, L. cavillone, C. cuculus and $C$. lastoviza dominating the species guild.

The Alboran Sea is featured by the lowest relative biomass of gurnards; the two Lepidotrigla species are the most common gurnards and the grey gurnard is absent. This peculiarity can be related to the influence of Atlantic inputs and the semi-permanent Almería-Oran hydrographic front, which plays a key role in defining the Alboran Sea as a specific fish fauna area within the northern Mediterranean Sea (Gaertner et al. 2005).

In the Adriatic region, the guild is dominated by L. cavillone, A. cuculus and C. lucerna. Here gurnards were found to be more abundant on the east than on the west side of the basin, probably also due to the eastward ontogenetic migration of the juveniles towards the Croatian coasts, as observed for $C$. cuculus (Vallisneri et al. 2014). Interesting is the absence in this region of the longfin gurnard (C. obscurus), which was also absent in Crete (GSA 23), as reported also by Tsimenides et al. (1992), and in Cyprus (GSA 25). The longfin gurnard also appears rare in the Aegean Sea, where it was not found in a study carried out in the 1970s (Papaconstantinou 1983). In this region, the four most abundant gurnards, in order of importance, were found to be $C$. cuculus, C. lastoviza, C. lucerna and L. cavillone.

The species displaying the highest geographical differences are E. gurnardus and P. cataphractum. The first is abundant only in the Gulf of Lions, rare in most of the GSAs and absent in the southern Tyrrhenian (GSA 10), Crete and Cyprus. The dominance of E. gurnardus on the continental shelf of the Gulf of Lions was already reported by Campillo et al. (1992). $P$. cataphractum is consistently more abundant in the Maltese waters than in all the other GSAs.

In terms of overall abundance, the Balearic Islands (GSA 5), Maltese waters (GSA 15), the Gulf of Lions
(GSA 7), eastern Corsica (GSA 8) and the eastern Ionian Sea (GSA 20) are the areas with the highest relative biomass of gurnards, while the lowest biomasses are observed in the Alboran and Tyrrhenian seas (GSAs 9 and 10), on the Italian side of the Adriatic (GSA 17a) and in the western Ionian Sea (GSA 19). At first glance this pattern in gurnard abundance could likely be the result of the current distribution of trawl fleets and fishing effort in the Mediterranean (see Colloca et al. 2017, Ferrà et al. 2018). The areas with the highest gurnard relative biomass are those that have the lowest trawl pressure on the continental shelf, while the opposite is observed in areas that have a high effort. Trawl catchability of gurnards is probably high since they live close to the sea bottom, mostly on soft and detrital sediments that are easily exploitable by trawlers. Some local studies support this hypothesis. For example, gurnards were the species showing the highest rate of abundance increase (about 500 fold) on the outer shelf (50-100 $\mathrm{m}$ ) of northwest Sicily after some years of trawling ban (Pipitone et al. 2000). In the Ionian Sea species like $T$. lyra, $L$. dieuzeidei and $P$. cataphractum were several times more abundant on the poorly exploited continental slope of Greece than on the intensively exploited Italian fishing grounds (D'Onghia et al. 2003). Similarly, in the northern sector of the Strait of Sicily the abundance of gurnards on poorly exploited fishing grounds on the continental slope was several time higher than in the traditionally exploited areas (Gristina et al. 2006). In the same region, Dimech et al. (2008) found higher relative biomass of $C$. cuculus and L. cavillone inside the less exploited Fisheries Management Zone (FMZ) of Malta than in the areas outside the FMZ. This evidence supports the hypothesis that the observed geographical differences in gurnard abundance may result from the different levels of fishing pressure, with areas less impacted by fishing hosting a higher gurnard biomass. Although more investigation is required on the subject, the results of our study point to a possible future use of gurnards as indicators of the fishing pressure exerted on the ecosystem and, as such, a useful tool for monitoring the fishing impact on the demersal fish communities. A summary of the trend observed since the mid-1990s by species and areas is provided in Figure 14 using a traffic light approach. In the western Mediterranean, a general decrease was found for the shallowest species (C. obscurus, $C$. lastoviza and C. lucerna), while a "green" status was more common for the upper slope species (T. lyra and $P$. cataphractum). A better situation was observed in the Ionian ecoregion (GSAs 15, 16, 19 and 20), where the "green" status was common for the deep-shelf (e.g. Lepidotrigla spp., C. cuculus) and upper-slope species. The only significant linear decrease in this region was found for C. obscurus and C. lastoviza in the south of Sicily.

The opposite was observed in the Aegean Sea (GSAs 22-23) and in Cyprus, where the trend was generally positive or stable for the shelf species, with most of the red lights found for deep-shelf and slope gurnard (Fig. 14). A shifting of fishing activities of Greek vessels towards slope resources has recently 


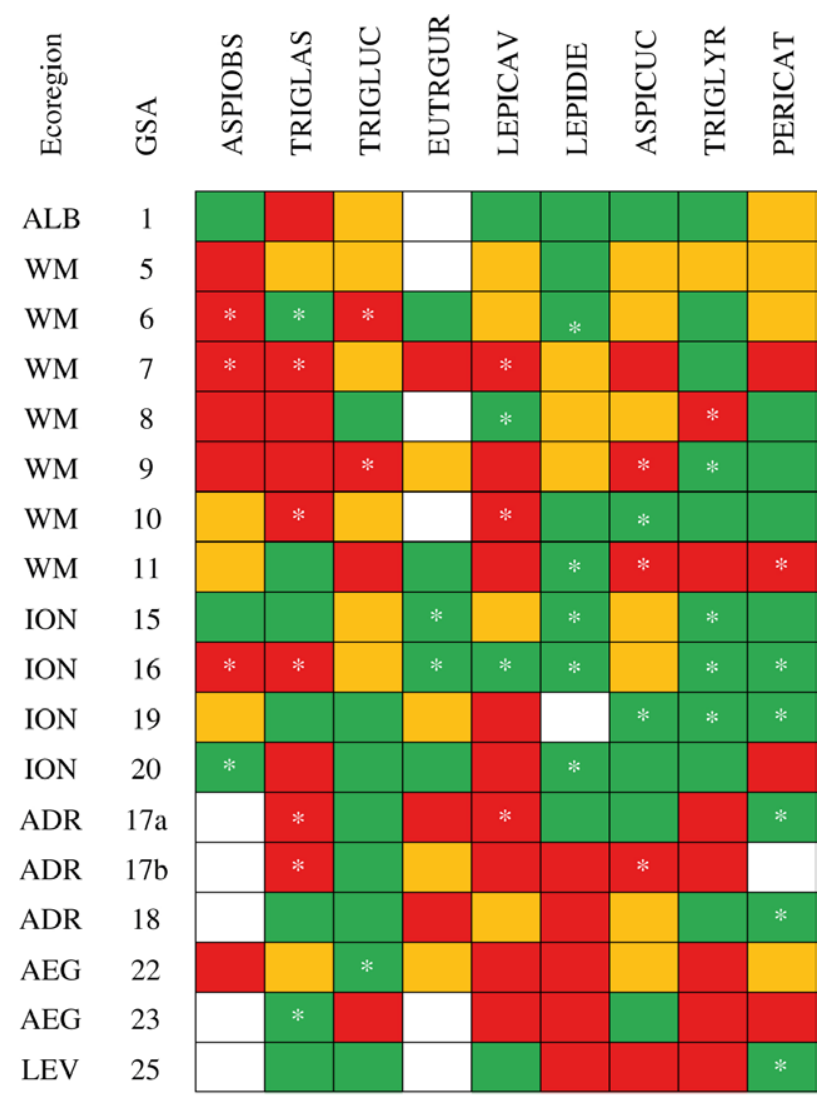

Fig. 14. - Temporal trend in MEDITS biomass index $\left(B I_{y}: \mathrm{kg}\right.$ $\mathrm{km}^{-2}$ ) of Mediterranean gurnards displayed using traffic lights: red, decreasing; green, increasing; orange, stable. Only $B I_{y}$ variation higher than $30 \%$ between the initial and final MEDITS period were considered as significant. *, significant linear trend in $B I_{y}:(\mathrm{p}<0.05)$. Species code as in Figure 2.

been postulated as an effect of the implementation of EC regulation 1967/2006, which bans bottom trawl activities within 1.5 nautical miles off the coast (Tserpes et al. 2016).

Similarly, deep-water gurnards in Sardinian waters showed the lowest relative biomasses in recent years, with the exception of $L$. dieuzeidei. P. cataphractum in particular showed a significant linear decrease in abundance across years, in strong contrast with all other ecoregions and GSAs. This temporal pattern may, besides ecological factors, reflect the modernization of the trawling fishing fleet that took place in the Sardinian fisheries (Marongiu et al. 2017), allowing fishing pressure to shift towards deeper habitats such as those inhabited by $P$. cataphractum.

While there is clear evidence that the excess fishing pressure is reducing the sizes of the gurnard populations in many Mediterranean sectors, there are still important aspects related to the ecology of this guild of species that would be worth exploring in order to understand the factors driving species abundance and distribution. One key feature is related to the habitat preferences of the species. Gurnards seem to prefer detrital sediments on both the continental shelf and slope. L. cavillone and C. cuculus off the western coasts of Italy appear more abundant on the detrital bottoms over the continental shelf break (Serena et al. 1990, Colloca et al. 1997, Damalas et al. 2010). L. diuzeidei was found to be more common on the detrital and muddy bottoms of the shallow part of the upper slope (Voliani et al. 2000), while on the coastal shelf, C. lucerna was concentrated on the coastal and detrital sandy bottoms and $C$. lastoviza on the coastal detrital sediments (Serena et al. 1990, Ordines et al. 2014). In this study, we found that the areas showing the highest gurnard abundances are those characterized by the prevalence or the wide extension of detrital bottoms, such as Malta, the Balearic Islands, the Greek GSAs and the south of Sicily, the latter characterized by wide offshore banks (Di Lorenzo et al. 2018). Another important aspect is connected with the occurrence of "refugia", where large spawners of species like $C$. lucerna can find protection from trawling, as was observed in the western Ionian Sea (D’Onghia et al. 2017).

The rapid ongoing warming of the Mediterranean is another key factor that, in combination with fishing pressure, might explain the species temporal trends observed. The increase in water temperature can be potentially beneficial for sub-tropical species such as the harmoured searobin but have a negative effect on the temperate ones such as E. gurnardus). The overall effect may be a progressive shift in gurnard distribution and abundance as effects of climate forcing. The NAO index, for example, was found to have an indirect effect on triglids by shaping their prey's availability (López-López et al. 2011). In Portuguese waters the landings of the large-scaled gurnard, a species with a sub-tropical affinity, decreased unexpectedly during the warm years (Teixeira et al. 2014). On the other hand, the congeneric sub-tropical L. dieuzeidei has expanded its distribution range in the Atlantic as an effect of the water temperature increase (Punzón et al. 2016).

Future studies on Mediterranean gurnards should focus on the above aspects, in order to understand specifically how fishing pressure, climate forcing and habitat suitability interact to determine the trends observed in the present study. Other important aspects that would be worth exploring are related to the compensatory effects that may occur within the gurnards guild. The nine species of gurnards inhabiting the Mediterranean basin exploit similar trophic niches, preying on the same groups of crustaceans. Therefore, a decrease in the abundance of one or more of these species could be compensated by the increase and the expansion of the more tolerant species, thus avoiding a functional diversity loss in the ecosystem.

\section{REFERENCES}

Anonymous. 2017. MEDITS-Handbook. Version n. 9, MEDITS Working Group, 106 pp.

http://www.sibm.it/MEDITS\%202011/principaledownload. htm

Bertrand J.A., Gil De Sola L., Papaconstantinou C., et al. 2002. The general specifications of the Medits survey. Sci. Mar. 66: 9-17. https://doi.org/10.3989/scimar.2002.66s29

Campillo A. 1992. Les pêcheries françaises de Méditerranée. Synthèse des connaissances. Rapports Internes de la Direction des Ressources Vivantes de l'Ifremer, RIDRV 92/019 RH Sète: 206 pp.

Cardinale M., Osio G.C., Scarcella G. 2017. Mediterranean Sea: a failure of the European fisheries management system. Front. 
Mar. Sci. 4: 72 https://doi.org/10.3389/fmars.2017.00072

Cleveland W.S, Grosse E., Shyu WM. 1992. Local regression models. Chapter 8 of Statistical Models, In: Chambers J.M., Hastie T.J. (eds), Wadsworth \& Brooks/Cole Springer-Verlag.

Colloca F., Ardizzone G.D., Gravina M.F. 1994. Trophic ecology of gurnards (Pisces: Triglidae) in the central Mediterranean Sea. Marine Life 4: 45-57.

Colloca F., Cardinale M., Ardizzone G.D. 1997. Biology, spatial distribution and population dynamics of Lepidotrigla cavillone (Pisces, Triglidae) in the central Tyrrhenian Sea. Fish. Res. 32: 21-32. https://doi.org/10.1016/S0165-7836(97)00041-6

Colloca F., Cardinale M., Marcello A., et al. 2003. Tracing the life history of red gurnard (Aspitrigla cuculus) using validated otolith annual rings. J. Appl. Ichthyol. 19: 1-9. https://doi.org/10.1046/j.1439-0426.2003.00342.x

Colloca F., Carpentieri P., Balestri E., et al. 2010. Food resource partitioning in a Mediterranean demersal fish assemblage: the effect of body size and niche width. Mar. Biol. 157: 565-574. https://doi.org/10.1007/s00227-009-1342-7

Colloca F., Cardinale M., Maynou F. et al. 2013. Rebuilding Mediterranean fisheries: a new paradigm for ecological sustainability. Fish. Fish. 14: 89-109. https://doi.org/10.1111/j.1467-2979.2011.00453.x

Colloca F., Scarcella G., Libralato S. 2017. Recent trends and impacts of fisheries exploitation on Mediterranean stocks and ecosystems. Front. Mar. Sci. 4: 244. https://doi.org/10.3389/fmars. 2017.00244

Cook R.M., Heath M.R. 2018. Population trends of bycatch species reflect improving status of target species. Fish. Fish. 19: 455-470. https://doi.org/10.1111/faf.12265

Damalas D., Maravelias C.D., Katsanevakis S., et al. 2010. Seasonal abundance of non-commercial demersal fish in the eastern Mediterranean Sea in relation to hydrographic and sediment characteristics. Est. Coast. Shelf. Sci. 89: 107-118 https://doi.org/10.1016/j.ecss.2010.06.002

Di Lorenzo M., Sinerchia M., Colloca F. 2018. The North sector of the Strait of Sicily: a priority area for conservation in the Mediterranean Sea. Hydrobiologia 821: 235-253. https://doi.org/10.1007/s10750-017-3389-7

Dimech M., Camilleri M., Hiddink J.G., et al. 2008. Differences in demersal community structure and biomass size spectra within and outside the Maltese Fishery Management Zone (FMZ). Sci. Mar. 72: 669-682. https://doi.org/10.3989/scimar.2008.72n4669

D’Onghia G., Mastrototaro F., Matarrese A., et al. 2003. Biodiversity of the upper slope demersal community in the eastern Mediterranean: preliminary comparison between two areas with and without trawl fishing. J. Northwest. Atl. Fish. Soc. 31: 263. https://doi.org/10.2960/J.v31.a20

D’Onghia G., Calculli C., Capezzuto F., et al. 2017. Anthropogenic impact in the Santa Maria di Leuca cold-water coral province (Mediterranean Sea): Observations and conservation straits. Deep-Sea Res. II 145: 87-101. https://doi.org/10.1016/j.dsr2.2016.02.012

Ferrà C., Tassetti A.N., Grati F., et al. 2018. Mapping change in bottom trawling activity in the Mediterranean Sea through AIS data. Mar. Pol. 94: 275-281. https://doi.org/10.1016/j.marpol.2017.12.013

Gaertner J.C., Bertrand J.A., De Sola L.G., et al. 2005. Large spatial scale variation of demersal fish assemblage structure on the continental shelf of the NW Mediterranean Sea. Mar. Ecol. Prog. Ser. 297: 245-257. https://doi.org/10.3354/meps297245

Gristina M., Bahri T., Fiorentino F., et al. 2006. Comparison of demersal fish assemblages in three areas of the Strait of Sicily under different trawling pressure. Fish. Res. 81: 60-71. https://doi.org/10.1016/j.fishres.2006.05.010

Jukic-Peladic S., Vrgoc N., Krstulovic-Sifner S., et al. 2001. Longterm changes in demersal resources of the Adriatic Sea: comparison between trawl surveys carried out in 1948 and 1998. Fish. Res. 53: 95-104 https://doi.org/10.1016/S0165-7836(00)00232-0

Kindt R., Coe R. 2005. Tree diversity analysis. A manual and software for common statistical methods for ecological and biodiversity studies. World Agroforestry Centre (ICRAF), Nairobi.

Labropoulou M., Papaconstantinou C. 2004. Community structure and diversity of demersal fish assemblages: the role of fishery.
Sci. Mar. 68S1: 215-226. https://doi.org/10.3989/scimar.2004.68s1215

López-López L., Preciado I., Velasco F., et al. 2011. Resource partitioning amongst five coexisting species of gurnards (Scorpaeniforme: Triglidae): Role of trophic and habitat segregation. J. Sea Res. 66: 58-68. https://doi.org/10.1016/j.seares.2011.04.012

Marongiu M.F., Porcu C., Bellodi A., et al. 2017. Temporal dynamics of demersal chondrichthyan species in the central western Mediterranean Sea: The case study in Sardinia Island. Fish. Res. 193: 81-94. https://doi.org/10.1016/j.fishres.2017.04.001

Massuti E., Reñones O. 2005. Demersal resource assemblages in the trawl fishing grounds off the Balearic Islands (Western Mediterranean). Sci. Mar. 69: 167-181. https://doi.org/10.3989/scimar.2005.69n1167

Montanini S., Stagioni M., Benni E., et al. 2017. Feeding strategy and ontogenetic changes in diet of gurnards (Teleostea: Scorpaeniformes: Triglidae) from the Adriatic Sea. Eur. Zool. J. 84: 356-367. https://doi.org/10.1080/24750263.2017.1335357

Morte M.S., Redon M.J., Sanz-Brau A. 1997. Trophic relationships between two gurnards Trigla lucerna and Aspitrigla obscura from the western Mediterranean. J. Mar. Biol. Ass. U.K. 77: 527-537. https://doi.org/10.1017/S0025315400071848

Ordines F., Farriols M.T., Lleonart J., et al. 2014. Biology and population dynamics of by-catch fish species of the bottom trawl fishery in the western Mediterranean. Medit. Mar. Sci. 15: 613-625. https://doi.org/10.12681/mms.812

Papaconstantinou C. 1981. Age and growth of piper, Trigla lyra, in Saronikos Gulf (Greece). Cybium 5: 73-87.

Papaconstantinou C. 1983. Observations on the ecology of gurnards (Pisces: Triglidae) in the Greek Seas. Cybium 7: 71-88.

Papaconstantinou C. 1984. Age and growth of the yellow gurnard (Trigla lucerna L. 1758) from the Thermaikos Gulf (Greece) with some comments on its biology. Fish. Res. 2: 243-255. https://doi.org/10.1016/0165-7836(84)90028-6

Pipitone C., Badalamenti F., D’Anna G., et al. 2000. Fish biomass increase after a four-year trawl ban in the Gulf of Castellammare (NW Sicily, Mediterranean Sea). Fish. Res. 48: 23-30. https://doi.org/10.1016/S0165-7836(00)00114-4

Punzón A., Serrano A., Sánchez F., et al. 2016. Response of a temperate demersal fish community to global warming. J. Mar. Sys. 161: $1-10$. https://doi.org/10.1016/j.jmarsys.2016.05.001

Richards W.J., Jones D.L. 2002. Preliminary classification of the gurnards (Triglidae: Scorpaeniformes). N. Z. J. Mar. Freshw. Res. 53: 274-282. https://doi.org/10.1071/MF01128

Serena F., Baino R., Voliani A. 1990. Distribuzione dei Triglidi (Osteichthyes, Scorpaeniformes) nell'Alto Tirreno. Oebalia Suppl. XVI: 269-278.

Spalding M.D., Fox H.E., Allen G.R., et al. 2007. Marine Ecoregions of the World: a bioregionalization of coast and shelf areas. BioScience 57: 573-583. https://doi.org/10.1641/B570707

Terrats A., Petrakis G., Papaconstantinou C. 2000. Feeding habits of Aspitrigla cuculus (L., 1758) (red gurnard), Lepidotrigla cavillone (Lac., 1802) (large scale gurnard) and Trigloporus lastoviza (Brunn., 1768) (rock gurnard) around Cyclades and Dodecanese Islands (E. Mediterranean). Medit. Mar. Sci. 1: 91-104. https://doi.org/10.12681/mms.280

Teixeira C.M., Gamito R., Leitão F., et al. 2014. Trends in landings of fish species potentially affected by climate change in Portuguese fisheries. Reg. Environ. Change 14: 657-669. https://doi.org/10.1007/s10113-013-0524-5

Tserpes G., Nikolioudakis N., Maravelias C., et al. 2016. Viability and management targets of Mediterranean demersal fisheries: the case of the Aegean Sea. PloS ONE 11: e0168694. https://doi.org/10.1371/journal.pone.0168694

Tsimenides N., Machias A., Kallioniotis A. 1992. Distribution patterns of Triglids (Pisces: Triglidae) on the Cretan shelf (Greece), and their interspecific associations. Fish. Res. 15: 83-103. https://doi.org/10.1016/0165-7836(92)90006-H

Vallisneri M., Stagioni M., Montanini S., et al. 2011. Body size, sexual maturity and diet in Chelidonichthys lucerna (Osteichthyes: Triglidae) from the Adriatic Sea, north eastern Mediter- 
ranean. Acta Adriat. 51: 141-148.

Vallisneri M., Montanini S., Stagioni M. 2012. Size at maturity of triglid fishes in the Adriatic Sea, northeastern Mediterranean. J. Appl. Ichthyol. 28: 123-125.

https://doi.oro/10.1111/j.1439-0426.2011.01777.x

Vallisneri M., Tommasini S., Stagioni M., et al. 2014. Distribution and some biological parameters of the red gurnard Chelidonich- thys cuculus (Actinopterygii, Scorpaeniformes, Triglidae) in the north-central Adriatic sea. Acta Ichthyol. Piscat. 44: 173-180. https://doi.org/10.3750/AIP2014.44.3.01

Voliani A., Mannini P., Auteri R. 2000. Distribuzione e biologia di Lepidotrigla cavillone (Lacepedè) e L. dieuzeidei (Auduin in Blanc e Hureau) nell' Arcipelago Toscano. Biol. Mar. Medit. 7: 844-849.

\section{APPENDICES}

Appendix 1. - Lepidotrigla cavillone. Mean MEDITS biomass index (BI $\left.: \mathrm{kg} \mathrm{km}^{-2}\right)$ per GSA and year from 1994 to 2015 in the $36-187 \mathrm{~m}$ depth range where $90 \%$ of positive hauls occurred. The proportional rate of change (\% change) in $B I_{y}$ was calculated between the first and the last three years of the time series in the GSAs where a significant linear trend in $B I_{y}$ was found.

\begin{tabular}{|c|c|c|c|c|c|c|c|c|c|c|c|c|c|c|c|c|c|c|c|c|c|c|c|}
\hline GSA & 94 & 95 & 96 & 97 & 98 & 99 & 00 & 01 & 02 & 03 & 04 & 05 & 06 & 07 & 08 & 09 & 10 & 11 & 12 & 13 & 14 & 15 & $\begin{array}{c}\% \\
\text { change }\end{array}$ \\
\hline 1 & 0.7 & 0.0 & 0.3 & 0.0 & 5.4 & 1.9 & 0.2 & 2.0 & 1.7 & 0.7 & 1.2 & 3.6 & 3.0 & 7.3 & 4.4 & 1.8 & 0.3 & 9.2 & 0 . & 0.4 & 1.7 & 1.1 & \\
\hline 5 & & & & & & & & & & & & & & 21.8 & 8.0 & 13.3 & 16.1 & 13.4 & 13.2 & 9.1 & 13.4 & 10.2 & \\
\hline 6 & 5.1 & 7.2 & 2.3 & 3.4 & 3.3 & 2.8 & 2.1 & 2.3 & 1.7 & 1.4 & 3.5 & 3.6 & 5.7 & 5.6 & 1.0 & 3.2 & 1.6 & 2.5 & 2.0 & 3.9 & 4.0 & 6.0 & \\
\hline 7 & 32.4 & 35.2 & 44.0 & 16.0 & 23.3 & 51.2 & 15.7 & 23.0 & 18.4 & 19.3 & 10.3 & 7.5 & 8.3 & 13.0 & 18.8 & 11.4 & 9.1 & 8.4 & 9.1 & 15.5 & 8.4 & 10.6 & -69.1 \\
\hline 8 & 12.7 & 20.3 & 0.0 & 18.8 & 9.5 & 22.0 & 10.3 & 15.4 & & 9.8 & 8.0 & 16.2 & 13.2 & 10.6 & 24.5 & 29.1 & 11.3 & 27.3 & 31.7 & 30.0 & 10.8 & 28.3 & 109.3 \\
\hline 9 & 6.4 & 3.8 & 3.9 & 3.8 & 3.8 & 4.8 & 4.8 & 3.2 & 4.7 & 1.8 & 3.4 & 2.8 & 2.9 & 3.6 & 4.4 & 4.5 & 5.5 & 3.6 & 5.5 & 3.2 & 4.0 & 1.6 & \\
\hline 10 & 7.9 & 16.2 & 15.8 & 5.9 & 16.9 & 11.2 & 11.5 & 1.2 & 11.7 & 5.5 & 1.3 & 6.1 & 5.7 & 8.6 & 3.5 & 9.8 & 9.0 & 10.6 & 11.7 & 4.4 & 3.7 & 1.8 & -75.1 \\
\hline 11 & 19.7 & 6.8 & 9.0 & 11.6 & 14.9 & 11.6 & 15.3 & 29.4 & 2.3 & 6.1 & 9.7 & 12.0 & 10.4 & 29.1 & 8.8 & 14.8 & 15.8 & 7.3 & 9.8 & 4.2 & 3.0 & 6.7 & \\
\hline 15 & & & & & & & & & & & & 14 & 41.5 & 39.7 & 44.0 & 33.3 & 16.0 & 35.8 & 20.4 & 25.8 & 26.3 & 26.6 & \\
\hline 16 & 5.6 & 4.7 & 3.0 & 7.1 & 5.5 & 6.1 & 8.4 & 4.9 & 15.5 & 2.1 & 11.2 & 26.0 & 17.6 & 14.5 & 23.0 & 21.0 & 25.9 & 10.9 & 8.2 & 14.2 & 20.0 & 8.8 & 224.0 \\
\hline 17 & 0.1 & 3.2 & 3.8 & 3.1 & 0.8 & 2.0 & 2.3 & 0.9 & 1.2 & 1.1 & 3 & 1.1 & 0.8 & 0.9 & 1.4 & 1.2 & 2.0 & 0.9 & 1. & 0.9 & 1.0 & 0.8 & -62.9 \\
\hline $17 \mathrm{~b}$ & & & 12.6 & 6.3 & 4.9 & & 7.6 & 5.6 & 8.2 & 4.2 & 13.3 & 14.0 & 7.8 & 5.7 & 15.8 & 18.7 & 12.4 & 7.0 & 12.8 & 6.0 & 4.6 & 8.4 & \\
\hline 18 & 1.2 & 1.4 & 1.3 & 1.3 & 1.7 & 4.6 & 3.7 & 11.1 & 13.7 & 2.3 & 3.6 & 10.8 & 2.8 & 1.3 & 2.2 & 3.3 & 6.9 & 5.1 & 6.0 & 0.7 & 3.1 & 0.5 & \\
\hline 19 & 9.9 & 0.6 & 0.5 & 0.0 & 0.2 & 0.0 & 0.1 & 0.2 & 5.3 & 1.0 & 3.7 & 1.1 & 1.4 & 0.4 & 1.8 & 0.5 & 0.3 & 0.7 & 2.0 & 1.3 & 2.6 & 1.3 & \\
\hline 20 & 8.9 & 10.5 & 27.0 & 11.3 & 23.0 & 15.6 & 18.2 & 16.0 & & 15.5 & 22.7 & 69.9 & 25.8 & & 25.3 & & & & & & 7.8 & & \\
\hline 22 & 11.2 & 14.5 & 13.3 & 11.5 & 12.4 & 13.1 & 17.2 & 7.3 & & 9.8 & 8.1 & 13.3 & 3.5 & & 9.5 & & & & & & 3.6 & & \\
\hline 23 & 16.7 & 35.9 & 24.8 & 15.9 & 27.2 & 42.3 & 5.4 & 20.0 & & 29.8 & 19.6 & 7.2 & 8.1 & & 26.5 & & & & & & 0.0 & & \\
\hline 25 & & & & & & & & & & & & 8.8 & 10.3 & 11.8 & 6.9 & 9.8 & 4.5 & 7.3 & 12.1 & 35.0 & & 18.4 & \\
\hline
\end{tabular}

Appendix 2. - Lepidotrigla dieuzeidei. Mean MEDITS biomass index ( $\left.B I_{y}: \mathrm{kg} \mathrm{km}^{-2}\right)$ per GSA and year from 1994 to 2015 in the $70-360 \mathrm{~m}$ depth range where $90 \%$ of positive hauls occurred. The proportional rate of change (\% change) in $B I_{y}$, was calculated between the first and the last three years of the time series in the GSAs where a significant linear trend in $B I_{y}$ was found.

\begin{tabular}{|c|c|c|c|c|c|c|c|c|c|c|c|c|c|c|c|c|c|c|c|c|c|c|c|}
\hline GSA & 94 & 95 & 96 & 97 & 98 & 99 & 00 & 01 & 02 & 03 & 04 & 05 & 06 & 07 & 08 & 09 & 10 & 11 & 12 & 13 & 14 & 15 & $\begin{array}{c}\% \\
\text { change }\end{array}$ \\
\hline 1 & 0.0 & 0.0 & 0.0 & 0.0 & 0.0 & 0.0 & 0.0 & 0.0 & 0.0 & 0.0 & 0.0 & 0.0 & 0.0 & & 0.1 & 0.0 & 0.0 & 0.0 & 0.4 & 0.3 & 3.5 & 0.8 & + \\
\hline 5 & & & & & & & & & & & & & & 3.8 & 3.7 & 12.4 & 11.7 & 14.9 & 19.3 & 8.6 & 11.8 & 9.2 & \\
\hline 6 & 0.0 & 0.0 & 0.01 & 0.0 & 0.0 & 0.0 & 0.0 & 0.0 & 0.0 & 0.0 & 0.0 & 0.1 & 0.0 & 0.0 & 0.0 & 0.0 & 0.0 & 0.0 & 0.0 & 0.0 & 0.5 & 0.6 & 10046.4 \\
\hline 7 & 0.0 & 0.2 & 0.6 & 1.1 & 0.5 & 2.5 & 2.7 & 1.1 & 1.4 & 0.8 & 0.8 & 0.1 & 0.8 & 2.4 & 0.7 & 0.1 & 0.1 & 1.3 & 1.0 & 1.2 & 1.3 & 0.8 & \\
\hline 8 & 21.8 & 20.3 & 34.5 & 6.8 & 0.1 & 40.5 & 5.3 & 50.2 & & 18.2 & 15.1 & 25.8 & 34.3 & 48.4 & 20.8 & 0.7 & 31.2 & 29.4 & 14.3 & 19.3 & 34.1 & 23.8 & \\
\hline 9 & 0.3 & 1.2 & 3.2 & 3.3 & 6.5 & 3.1 & 2.6 & 0.3 & 1.1 & 14.1 & 4.2 & 3.6 & 1.9 & 1.4 & 2.4 & 5.0 & 5.7 & 4.3 & 2.1 & 1.2 & 1.5 & 3.7 & \\
\hline 10 & 0.0 & 0.0 & 0.0 & 0.0 & 0.0 & 0.0 & 0.0 & 0.0 & 0.0 & 0.0 & 0.0 & 1.5 & 0.0 & 0.0 & 0.0 & 1.1 & 0.8 & 0.7 & 0.5 & 0.6 & 0.7 & 0.5 & + \\
\hline 11 & 2.6 & 4.7 & 7.5 & 2.9 & 16.8 & 20.7 & 4.8 & 18.1 & 10.0 & 11.8 & 2.5 & 9.2 & 11.4 & 14.3 & 2.6 & 18.3 & 10.3 & 22.8 & 19.9 & 10.8 & 8.1 & 23.7 & 187.2 \\
\hline 15 & & & & & & & & & & & & 0.0 & 0.0 & 2.8 & 6.8 & 12.7 & 5.4 & 16.3 & 10.3 & 9.5 & 10.4 & 6.4 & 843.1 \\
\hline 16 & 0.0 & 0.0 & 0.05 & 0.0 & 0.0 & 0.0 & 0.0 & 0.0 & 0.0 & 7.6 & 2.8 & 0.0 & 3.4 & 5.5 & 25.3 & 14.3 & 5.7 & 5.1 & 5 & 8.7 & 4.6 & 4.1 & 35838.2 \\
\hline $17 \mathrm{a}$ & 0.0 & 0.0 & 0.0 & 0.0 & 0.9 & 0.2 & 0.2 & 0.0 & 0.5 & 0.0 & 0.1 & 0.2 & 0.0 & 0.0 & 0.9 & 0.3 & 0.2 & 0.1 & 0. & 0.1 & 0.3 & 0.1 & + \\
\hline $17 \mathrm{~b}$ & & & 0.3 & 0.0 & 0.0 & & 0.8 & 0.0 & 0.4 & 0.7 & 2.5 & 1.3 & 0.2 & 0.7 & 1.3 & 0.1 & 1.5 & 0.4 & 0.6 & 0.2 & 0.2 & 0.4 & \\
\hline 18 & 0.0 & 0.0 & 0.0 & 0.0 & 0.0 & 0.05 & 0.0 & 0.0 & 0.0 & 0.0 & 0.0 & 0.3 & 0.0 & 0.0 & 0.1 & 9.5 & 1.1 & 0.9 & 1.7 & 2.0 & 0.6 & 0.0 & \\
\hline 19 & 0.0 & 0.0 & 0.0 & 0.0 & 0.0 & 0.0 & 0.0 & 0.0 & 0.0 & 0.0 & 0.0 & 0.0 & 0.0 & 0.0 & 0.0 & 0.0 & 0.0 & 0.0 & 0.0 & 0.0 & 0.0 & 0.0 & \\
\hline 20 & 0.0 & 0.0 & 4.6 & 0.9 & 3.1 & 4.1 & 5.1 & 11.5 & & 29.6 & 19.6 & 25.6 & 25.4 & & 19.4 & & & & & & 9.0 & & 485.5 \\
\hline 22 & 1.3 & 0.0 & 4.7 & 1.4 & 0.4 & 0.6 & 0.7 & 0.5 & & 3.1 & 6.1 & 3.4 & 2.6 & & 3.4 & & & & & & 0.7 & & \\
\hline 23 & 0.1 & 0.0 & 0.2 & 0.0 & 0.0 & 0.0 & 0.0 & 0.0 & & 0.0 & 0.3 & 0.0 & 0.0 & & 0.0 & & & & & & 0.0 & & \\
\hline 25 & & & & & & & & & & & & 1.0 & 1.2 & 1.6 & 0.0 & 0.1 & 0.1 & 0.0 & 0.0 & 0.0 & & 0.6 & \\
\hline
\end{tabular}


$114 \cdot$ F. Colloca et al..

Appendix 3. - Lepidotrigla spp. Mean MEDITS biomass index (BI $\left.: \mathrm{kg} \mathrm{km}^{-2}\right)$ per GSA and year from 1994 to 2015 in the $26-360 \mathrm{~m}$ depth range where $90 \%$ of positive hauls occurred. The proportional rate of change (\% change) in $B I_{y}$ was calculated between the first and the last three years of the time series in the GSAs where a significant linear trend in $B I_{y}$ was found.

\begin{tabular}{|c|c|c|c|c|c|c|c|c|c|c|c|c|c|c|c|c|c|c|c|c|c|c|c|}
\hline GSA & 94 & 95 & 96 & 97 & 98 & 99 & 00 & 01 & 02 & 03 & 04 & 05 & 06 & 07 & 08 & 09 & 10 & 11 & 12 & 13 & 14 & \multicolumn{2}{|c|}{15 change } \\
\hline 1 & 0.6 & 0.0 & 0.2 & 0.0 & 5.4 & 1.4 & 0.1 & 1.2 & 1.3 & 0.5 & 1.1 & 3.2 & 2.4 & 5.3 & 3.7 & 1.5 & 0.2 & 6.6 & 1.1 & 0.8 & 5.5 & 1.7 & 917.7 \\
\hline 5 & & & & & & & & & & & & & & 22.5 & 10.4 & 21.8 & 23.9 & 23.9 & 26.2 & $\begin{array}{r}0.0 \\
15.3\end{array}$ & 21.8 & 15.9 & \\
\hline 6 & 5.1 & 6.4 & 2.1 & 3.2 & 3.5 & 3.0 & 2.0 & 2.2 & 1.6 & 1.2 & 3.2 & 3.3 & 5.1 & 5.2 & 0.9 & 3.0 & 1.3 & 1.9 & 1.8 & 3.2 & 3.9 & 6.1 & \\
\hline 7 & 28.8 & 35.8 & 43.3 & 16.8 & 23.9 & 52.7 & 18.5 & 22.4 & 19.2 & 20.1 & 11.6 & 7.4 & 9.6 & 15.9 & 18.8 & 11.8 & 9.2 & 10.0 & 10.7 & 16.3 & 9.8 & 11.1 & -65.5 \\
\hline 8 & 12.7 & 16.4 & 29.8 & 9.6 & 7.8 & 22.0 & 10.6 & 31.2 & & 16.6 & 15.7 & 18.7 & 13.6 & 38.7 & 44.9 & 23.0 & 33.7 & 43.7 & 38.7 & 37.0 & 23.6 & 35.0 & 62.2 \\
\hline 9 & 6.1 & 4.6 & 6.8 & 6.7 & 10.2 & 7.2 & 6.5 & 3.9 & 4.9 & 17.4 & 7.2 & 6.6 & 4.6 & 4.5 & 6.4 & 9.6 & 12.7 & 8.0 & 7.0 & 3.7 & 4.5 & 4.9 & \\
\hline 10 & 5.9 & 12.7 & 10.9 & 4.6 & 14.7 & 11.4 & 10.3 & 7.0 & 7.9 & 4.3 & 1.1 & 6.7 & 6.1 & 6.1 & 3.8 & 8.8 & 7.9 & 9.5 & 9.9 & 4.3 & 3.7 & 2.2 & -65.5 \\
\hline 11 & 18.2 & 9.2 & 13.0 & 13.9 & 21.6 & 28.5 & 16.0 & 45.1 & 4.9 & 26.0 & 9.5 & 18.9 & 20.7 & 36.5 & 11.1 & 29.6 & 22.1 & 26.3 & 29.7 & 13.1 & 10.7 & 24.4 & \\
\hline 15 & & & & & & & & & & & & 126 & 42.7 & 42.4 & 44.5 & 41.4 & 19.0 & 48.1 & 30.2 & 31.7 & 34.7 & 29.8 & \\
\hline 16 & 4.4 & 3.4 & 2.1 & 5.8 & 4.3 & 4.2 & 6.6 & 4.0 & 13.0 & 31.7 & 12.7 & 20.1 & 17.8 & 21.5 & 45.8 & 32.4 & 28.3 & 13.7 & 12.2 & 22.3 & 20.9 & 11.9 & 459.3 \\
\hline $17 \mathrm{a}$ & 0.1 & 2.8 & 3.7 & 2.6 & 1.4 & 1.9 & 2.0 & 0.7 & 1.4 & 0.9 & 1.2 & 1.1 & 0.7 & 0.8 & 1.8 & 1.2 & 1.8 & 0.8 & 1.0 & 0.8 & 1.0 & 0.7 & -62.1 \\
\hline $17 \mathrm{~b}$ & & & 11.3 & 5.8 & 4.6 & & 8.1 & 4.8 & 7.8 & 4.2 & 13.9 & 13.6 & 7.2 & 5.5 & 15.3 & 16.7 & 12.4 & 6.4 & 11.4 & 4.9 & 3.7 & 7.1 & \\
\hline 18 & 0.9 & 1.1 & 1.2 & 1.2 & 1.7 & 5.2 & 3.4 & 10.5 & 13.0 & 2.3 & 3.5 & 10.3 & 2.6 & 1.2 & 2.1 & 3.6 & 7.1 & 5.5 & 5.9 & 2.3 & 3.4 & 0.5 & \\
\hline 19 & 8.9 & 0.6 & 0.4 & 0.0 & 0.1 & 0.0 & 0.1 & 0.2 & 3.5 & 0.6 & 2.7 & 0.8 & 1.0 & 0.3 & 1.3 & 0.4 & 0.2 & 0.5 & 1.3 & 0.9 & 1.9 & 0.9 & \\
\hline 20 & 6.4 & 8.5 & 35.6 & 13.1 & 24.2 & 16.4 & 18.1 & 24.3 & & 27.7 & 30.3 & 82.4 & 46.9 & & 45.2 & & & & & & 10.9 & & \\
\hline 22 & 10.0 & 10.6 & 12.4 & 9.9 & 10.4 & 10.8 & 14.1 & 6.6 & & 9.6 & 10.4 & 18.4 & 5.0 & & 31.3 & & & & & & 4.9 & & -55.1 \\
\hline 23 & 9.2 & 25.4 & 22.3 & 11.5 & 28.5 & 31.6 & 5.2 & 20.7 & & 32.0 & 18.1 & 6.5 & 8.0 & & 21.9 & & & & & & 0.0 & & \\
\hline 25 & & & & & & & & & & & & 8.8 & 10.1 & 11.5 & 6.3 & 8.9 & 4.2 & 6.6 & 11.1 & 31.3 & & 16.8 & \\
\hline
\end{tabular}

Appendix 4. - Chelidonichthys cuculus. Mean MEDITS biomass index $\left(B I_{y}: \mathrm{kg} \mathrm{km}^{-2}\right)$ per GSA and year from 1994 to 2015 in the $60-270 \mathrm{~m}$ depth range where $90 \%$ of positive hauls occurred. The proportional rate of change (\% change) in $B I_{y}$ was calculated between the first and the last three years of the time series in the GSAs where a significant linear trend in $B I_{y}$ was found.

\begin{tabular}{|c|c|c|c|c|c|c|c|c|c|c|c|c|c|c|c|c|c|c|c|c|c|c|c|}
\hline GSA & 94 & 95 & 96 & 97 & 98 & 99 & 00 & 01 & 02 & 03 & 04 & 05 & 06 & 07 & 08 & 09 & 10 & 11 & 12 & 13 & 14 & 15 & $\begin{array}{c}\% \\
\text { change }\end{array}$ \\
\hline 1 & 0.1 & 0.0 & 0.3 & 1.1 & 0.9 & 0.3 & 0.7 & 0.1 & 0.4 & 0.4 & 0.2 & 0.6 & 0.5 & 1.0 & 0.1 & 0.0 & 0.0 & 0.1 & 0.0 & 0.1 & 1.4 & 1.7 & \\
\hline 5 & & & & & & & & & & & & & & 70.5 & 33.3 & 40.6 & 70.1 & 62.8 & $\begin{array}{r}0.0 \\
49.8\end{array}$ & 39.2 & 68.7 & 23.5 & \\
\hline 6 & 2.0 & 3.1 & 0.9 & 0.6 & 7.6 & 3.0 & 2.3 & 7.1 & 0.9 & 1.9 & 2.1 & 4.5 & 8.2 & 9.5 & 1.0 & 1.8 & 1.6 & 3.5 & 3.7 & 3.6 & 4.3 & 4.6 & \\
\hline 7 & 8.3 & 11.2 & 12.4 & 7.9 & 8.5 & 18.9 & 9.6 & 16.0 & 6.2 & 6.4 & 4.5 & 4.9 & 8.4 & 11.8 & 8.4 & 3.9 & 7.7 & 6.3 & 8.4 & 13.3 & 4.6 & 4.4 & \\
\hline 8 & 8.1 & 10.4 & 20.1 & 6.4 & 45.8 & 19.3 & 10.6 & 19.7 & & 13.9 & 18.1 & 10.2 & 11.3 & 31.7 & 18.2 & 13.5 & 11.6 & 8.1 & 12.4 & 17.1 & 5.8 & 9.4 & \\
\hline 9 & 5.1 & 8.7 & 9.1 & 9.5 & 5.8 & 6.1 & 5.9 & 5.4 & 4.4 & 14.8 & 5.3 & 2.0 & 1.2 & 3.3 & 2.1 & 3.9 & 3.1 & $\begin{array}{l}0.1 \\
1.8\end{array}$ & 5.6 & 2.7 & 1.4 & 1.6 & -75.0 \\
\hline 10 & 0.4 & 0.4 & 0.2 & 0.0 & 0.5 & 0.5 & 9.9 & 0.8 & 2.1 & 5.9 & 7.6 & 12.6 & 7.5 & 4.6 & 4.5 & 8.1 & 8.2 & 7.2 & 7.9 & 7.0 & 3.8 & 1.7 & 1102.0 \\
\hline 11 & 22.3 & 22.0 & 18.4 & 8.6 & 12.3 & 30.0 & 10.1 & 43.4 & 19.2 & 22.0 & 13.1 & 23.4 & 14.0 & 36.3 & 7.1 & 11.2 & 7.7 & 10.1 & 7.6 & 1.0 & 1.6 & 6.6 & -85.3 \\
\hline 15 & & & & & & & & & & & & 8.1 & 11.4 & 13.3 & 17.3 & 14.0 & 11.2 & 11.6 & 13.1 & 8.8 & 17.3 & 13.4 & \\
\hline 16 & 7.9 & 33.0 & 17.3 & 3.9 & 3.7 & 1.6 & 4.0 & 4.0 & 16.2 & 15.5 & 20.6 & 29.8 & 32.4 & 33.6 & 32.3 & 25.0 & 30.5 & 12.2 & 14.7 & 18.5 & 22.9 & 17.9 & \\
\hline $17 \mathrm{a}$ & 0.1 & 0.6 & 0.5 & 0.6 & 0.2 & 1.9 & 2.6 & 0.2 & 2.3 & 0.8 & 0.5 & 0.6 & 0.3 & 1.7 & 1.2 & 0.5 & 0.4 & 1.8 & 0.9 & 0.4 & 1.2 & 0.5 & \\
\hline $17 \mathrm{~b}$ & & & 9.6 & 5.8 & 6.3 & & 30.6 & 6.9 & 25.7 & $\begin{array}{r}0.0 \\
11.7\end{array}$ & 13.9 & 6.1 & 6.2 & 13.1 & 8.7 & 3.2 & 6.7 & 0.6 & 2.1 & 2.2 & 3.6 & 1.8 & -73.7 \\
\hline 18 & 5.7 & 8.0 & 10.3 & 0.8 & 1.9 & 38.7 & 8.4 & 13.0 & 12.1 & 5.4 & 10.5 & 20.3 & 8.0 & 13.2 & 12.2 & 17.6 & 14.2 & 10.1 & 19.3 & 7.2 & 7.9 & 2.8 & \\
\hline 19 & 0.7 & 0.5 & 1.2 & 0.1 & 0.8 & 0.6 & 1.0 & 1.3 & 5.3 & 9.1 & 12.5 & 9.0 & 5.6 & 4.7 & 3.7 & 2.6 & 2.6 & 2.1 & 9.8 & 10.8 & 10.7 & 4.6 & 1039.8 \\
\hline 20 & 0.0 & 2.1 & 14.3 & 4.7 & 10.7 & 3.1 & 4.6 & 13.5 & & 17.9 & 9.5 & 18.7 & 15.7 & & 17.9 & & & & & & 7.1 & & \\
\hline 22 & 16.0 & 8.4 & 7.9 & 13.4 & 18.1 & 11.4 & 28.7 & 19.8 & & 40.7 & 28.9 & 32.1 & 22.4 & & 21.7 & & & & & & 11.5 & & \\
\hline 23 & 1.2 & 0.8 & 0.1 & 6.2 & 14.1 & 5.0 & 3.1 & 5.4 & & 33.7 & 9.0 & 13.4 & 12.4 & & 16.0 & & & & & & 6.0 & & \\
\hline 25 & & & & & & & & & & & & 10.7 & 19.4 & 11.7 & 4.8 & 1.7 & 3.0 & 1.6 & 3.2 & 3.1 & & 7.8 & \\
\hline
\end{tabular}

Appendix 5. - Chelidonichthys obscurus. Mean MEDITS biomass index $\left(B I_{y}: \mathrm{kg} \mathrm{km}^{-2}\right)$ per GSA and year from 1994 to 2015 in the $20-120 \mathrm{~m}$ depth range where $90 \%$ of positive hauls occurred. The proportional rate of change (\% change) in $B I_{y}$ was calculated between the first and the last three years of the time series in the GSAs where a significant linear trend in $B I_{y}$ was found.

\begin{tabular}{|c|c|c|c|c|c|c|c|c|c|c|c|c|c|c|c|c|c|c|c|c|c|c|c|}
\hline GSA & 94 & 95 & 96 & 97 & 98 & 99 & 00 & 01 & 02 & 03 & 04 & 05 & 06 & 07 & 08 & 09 & 10 & 11 & 12 & 13 & 14 & $15 \mathrm{c}$ & $\begin{array}{c}\% \\
\text { change }\end{array}$ \\
\hline 1 & 0.0 & 0.0 & 0.0 & 0.4 & 0.0 & 0.0 & 0.1 & 0.3 & 0.4 & 0.0 & 0.0 & 0.0 & 1.5 & 0.5 & 0.2 & 0.0 & 0.0 & 0.6 & 0.0 & 0.9 & 0.9 & 0.1 & \\
\hline 5 & & & & & & & & & & & & & & 0.5 & 0.0 & 0.0 & 0.0 & 0.0 & 0.0 & 0.0 & 0.0 & 0.0 & \\
\hline 6 & 0.1 & 1.8 & 0.3 & 0.1 & 0.1 & 0.0 & 0.6 & 0.2 & 0.2 & 0.0 & 0.1 & 0.2 & 0.3 & 0.2 & 0.0 & 0.1 & 0.0 & 0.1 & 0.1 & 0.1 & 0.1 & 0.1 & -87.9 \\
\hline 7 & 1.2 & 6.7 & 2.0 & 0.4 & 0.1 & 0.1 & 0.1 & 0.0 & 3.1 & 0.4 & 0.1 & 0.1 & 0.1 & 0.7 & 0.4 & 0.2 & 0.0 & 0.0 & 0.1 & 0.3 & 0.0 & 0.0 & -96.1 \\
\hline 8 & 0.0 & 0.2 & 0.0 & 0.0 & 0.0 & 0.0 & 0.0 & 0.0 & & 0.0 & 0.0 & 0.0 & 0.0 & 0.0 & 0.0 & 0.0 & 0.0 & 0.3 & 0.1 & 0.0 & 0.0 & 0.0 & \\
\hline 9 & 0.7 & 0.3 & 0.5 & 0.2 & 0.2 & 0.2 & 0.3 & 0.2 & 0.3 & 0.1 & 1.0 & 0.4 & 0.0 & 2.1 & 0.0 & 0.0 & 0.1 & 0.0 & 0.8 & 0.1 & 0.1 & 0.3 & \\
\hline 10 & 0.0 & 0.0 & 0.0 & 0.0 & 0.0 & 0.1 & 0.0 & 0.2 & 0.1 & 0.1 & 0.1 & 0.4 & 0.1 & 0.2 & 0.0 & 0.2 & 0.2 & 0.2 & 0.0 & 0.2 & 0.0 & 0.0 & \\
\hline 11 & 1.5 & 0.3 & 0.5 & 2.3 & 0.9 & 1.0 & 1.2 & 4.0 & 3.0 & 0.8 & 0.2 & 1.9 & 0.6 & 3.5 & 0.0 & 1.4 & 1.3 & 1.2 & 1.6 & 1.5 & 0.9 & 0.3 & \\
\hline 15 & & & & & & & & & & & & 0.0 & 0.7 & 0.2 & 0.5 & 0.0 & 0.0 & 0.0 & 0.0 & 0.3 & 0.0 & 1.0 & \\
\hline 16 & 1.2 & 5.2 & 7.8 & 14.3 & 3.2 & 3.3 & 9.2 & 2.0 & 2.5 & 5.3 & 8.8 & 1.7 & 1.6 & 3.1 & 4.4 & 3.0 & 4.7 & 6.3 & 1.2 & 2.5 & 0.2 & 1.1 & -64.6 \\
\hline $17 \mathrm{a}$ & 0.0 & 0.0 & 0.0 & 0.0 & 0.0 & 0.0 & 0.0 & 0.0 & 0.0 & 0.0 & 0.0 & 0.0 & 0.0 & 0.0 & 0.0 & 0.0 & 0.0 & 0.0 & 0.0 & 0.0 & 0.0 & 0.0 & \\
\hline $17 \mathrm{~b}$ & & & 0.0 & 0.0 & 0.0 & & 0.0 & 0.0 & 0.0 & 0.0 & 0.0 & 0.0 & 0.0 & 0.0 & 0.0 & 0.0 & 0.0 & 0.0 & 0.0 & 0.0 & 0.0 & 0.0 & \\
\hline 18 & 0.0 & 0.0 & 0.0 & 0.0 & 0.0 & 0.0 & 0.0 & 0.0 & 0.0 & 0.0 & 0.0 & 0.0 & 0.0 & 0.0 & 0.0 & 0.0 & 0.0 & 0.0 & 0.0 & 0.0 & 0.0 & 0.0 & \\
\hline 19 & 0.0 & 0.0 & 0.0 & 0.0 & 0.0 & 0.0 & 0.0 & 0.1 & 0.0 & 0.0 & 0.02 & 0.1 & 0.1 & 0.3 & 0.1 & 0.0 & 0.0 & 0.3 & 0.1 & 0.0 & 0.0 & 0.0 & \\
\hline 20 & 0.0 & 0.0 & 0.0 & 0.0 & 0.1 & 0.0 & 0.0 & 0.0 & & 0.0 & 0.0 & 0.2 & 0.0 & & 0.3 & & & & & & 0.1 & & 572.7 \\
\hline 22 & 0.0 & 0.04 & 0.0 & 0.0 & 0.0 & 0.0 & 0.1 & 0.0 & & 0.0 & 0.0 & 0.0 & 0.0 & & 0.0 & & & & & & 0.0 & & \\
\hline 23 & 0.0 & 0.0 & 0.0 & 0.0 & 0.0 & 0.0 & 0.0 & 0.0 & & 0.0 & 0.0 & 0.0 & 0.0 & & 0.0 & & & & & & 0.0 & & \\
\hline 25 & & & & & & & & & & & & 0.0 & 0.0 & 0.0 & 0.0 & 0.0 & 0.0 & 0.0 & 0.0 & 0.0 & & 0.0 & \\
\hline
\end{tabular}


Appendix 6. - Eutrigla gurnardus. Mean MEDITS biomass index (BI $: \mathrm{kg} \mathrm{km}^{-2}$ ) per GSA and year from 1994 to 2015 in the $30-165 \mathrm{~m}$ depth range where $90 \%$ of positive hauls occurred. The proportional rate of change (\% change) in $B I_{y}$ was calculated between the first and the last three years of the time series in the GSAs where a significant linear trend in $B I_{y}$ was found.

\begin{tabular}{|c|c|c|c|c|c|c|c|c|c|c|c|c|c|c|c|c|c|c|c|c|c|c|}
\hline GSA & 94 & 95 & 96 & 97 & 98 & 99 & 00 & 01 & 02 & 03 & 04 & 05 & 06 & 07 & 08 & 09 & 10 & 11 & 12 & 13 & 14 & $15 \begin{array}{c}\% \\
\text { change }\end{array}$ \\
\hline 1 & 0.0 & 0.0 & 0.0 & 0.0 & 0.0 & 0.0 & 0.0 & 0.0 & 0.0 & 0.0 & 0.0 & 0.0 & 0.0 & 0.0 & 0.0 & 0.0 & 0.0 & 0.0 & 0.0 & 0.0 & 0.0 & 0.0 \\
\hline 5 & & & & & & & & & & & & & & 0.0 & 0.0 & 0.0 & 0.2 & 0.2 & 0.0 & 0.0 & 0.0 & 0.1 \\
\hline 6 & 0.3 & 3.8 & 0.3 & 0.9 & 0.0 & 0.1 & 3.1 & 0.2 & 0.2 & 0.2 & 0.3 & 1.2 & 1.6 & 0.1 & 0.1 & 0.3 & 0.1 & 0.1 & 0.2 & 0.7 & 1.6 & 5.4 \\
\hline 7 & 46.210 & 08.1 & 53.0 & 22.6 & 16.9 & 22.2 & 35.9 & 38.5 & 44.4 & 27.9 & 28.5 & 22.0 & 39.4 & 31.6 & 53.3 & 47.4 & 36.5 & 25.5 & 37.2 & 35.9 & 11.7 & 10.5 \\
\hline 8 & 0.0 & 0.0 & 0.0 & 0.0 & 0.5 & 0.0 & 0.0 & 0.0 & & 0.0 & 0.0 & 0.0 & 0.0 & 0.0 & 0.0 & 0.0 & 0.0 & 0.0 & 0.0 & 0.0 & 0.0 & 0.2 \\
\hline 9 & 0.3 & 0.3 & 0.1 & 0.2 & 0.0 & 0.1 & 0.1 & 0.1 & 0.3 & 0.1 & 0.1 & 0.05 & 0.02 & 0.6 & 0.05 & 0.3 & 0.7 & 0.4 & 0.1 & 0.1 & 0.3 & 0.1 \\
\hline 10 & 0.0 & 0.0 & 0.0 & 0.0 & 0.0 & 0.0 & 0.0 & 0.0 & 0.0 & 0.0 & 0.0 & 0.0 & 0.0 & 0.0 & 0.0 & 0.0 & 0.0 & 0.0 & 0.0 & 0.0 & 0.0 & 0.0 \\
\hline 11 & 0.0 & 0.2 & 0.1 & 0.2 & 0.03 & 0.3 & 0.5 & 1.2 & 0.0 & 0.5 & 0.1 & 0.6 & 0.2 & 1.2 & 0.1 & 0.3 & 0.3 & 0.2 & 0.8 & 0.6 & 0.7 & 0.3 \\
\hline 15 & & & & & & & & & & & & 0.0 & 3.5 & 3.8 & 3.4 & 1.6 & 1.7 & 4.0 & 4.9 & 2.8 & 5.0 & $3.8 \quad 58.8$ \\
\hline 16 & 0.0 & 0.0 & 0.0 & 0.04 & 0.0 & 0.0 & 0.1 & 0.0 & 0.04 & 0.0 & 0.3 & 0.01 & 0.2 & 0.2 & 0.02 & 0.01 & 0.1 & 0.04 & 0.2 & 0.1 & 0.3 & 0.611008 .1 \\
\hline $17 \mathrm{a}$ & 1.1 & 0.5 & 0.6 & 0.3 & 0.3 & 1.6 & 1.8 & 0.7 & 3.5 & 3.0 & 2.6 & 2.2 & 1.7 & 0.9 & 1.4 & 0.4 & 0.5 & 0.6 & 0.4 & 0.3 & 0.5 & 0.6 \\
\hline $17 b$ & & & 4.0 & 1.0 & 1.0 & & 2.4 & 0.9 & 7.4 & 6.8 & 5.7 & 5.7 & 2.9 & 1.6 & 2.8 & 2.0 & 1.0 & 0.6 & 1.1 & 1.4 & 0.4 & 9.6 \\
\hline 18 & 0.1 & 0.3 & 0.1 & 0.04 & 0.0 & 0.2 & 0.3 & 0.4 & 2.3 & 0.4 & 0.7 & 0.3 & 0.2 & 0.1 & 0.4 & 0.5 & 0.3 & 0.2 & 0.2 & 0.2 & 0.1 & 0.03 \\
\hline 19 & 0.0 & 0.2 & 0.03 & 0.03 & 0.1 & 0.2 & 0.1 & 0.01 & 0.9 & 0.4 & 1.3 & 0.4 & 0.5 & 0.0 & 0.6 & 0.1 & 0.1 & 0.1 & 0.1 & 0.1 & 0.2 & 0.01 \\
\hline 20 & 0.2 & 0.0 & 0.8 & 0.0 & 0.1 & 0.2 & 0.7 & 2.4 & & 0.4 & 3.9 & 1.0 & 1.3 & & 1.2 & & & & & & 0.8 & \\
\hline 22 & 1.4 & 0.7 & 1.1 & 0.4 & 0.9 & 2.1 & 0.7 & 0.9 & & 4.4 & 2.1 & 3.2 & 2.8 & & 0.6 & & & & & & 1.4 & \\
\hline 23 & 0.0 & 0.0 & 0.0 & 0.0 & 0.0 & 0.0 & 0.0 & 0.0 & & 0.0 & 0.0 & 0.0 & 0.0 & & 0.0 & & & & & & 0.0 & \\
\hline 25 & & & & & & & & & & & & 0.0 & 0.0 & 0.0 & 0.0 & 0.0 & 0.2 & 0.0 & 0.01 & 0.0 & & 0.0 \\
\hline
\end{tabular}

Appendix 7. - Chelidonichthys lucerna. Mean MEDITS biomass index ( $\left.B I_{y}: \mathrm{kg} \mathrm{km}^{-2}\right)$ per GSA and year from 1994 to 2015 in the $15-175 \mathrm{~m}$ depth range where $90 \%$ of positive hauls occurred. The proportional rate of change (\% change) in $B I_{y}$ was calculated between the first and the last three years of the time series in the GSAs where a significant linear trend in $B I_{y}$ was found.

\begin{tabular}{|c|c|c|c|c|c|c|c|c|c|c|c|c|c|c|c|c|c|c|c|c|c|c|c|}
\hline GSA & 94 & 95 & 96 & 97 & 98 & 99 & 00 & 01 & 02 & 03 & 04 & 05 & 06 & 07 & 08 & 09 & 10 & 11 & 12 & 13 & 14 & 15 & $\begin{array}{c}\% \\
\text { change }\end{array}$ \\
\hline 1 & 0.6 & 0.0 & 0.0 & 0.0 & 1.4 & 0.6 & 1.9 & 1.9 & 0.5 & 0.2 & 0.0 & 0.0 & 0.6 & 0.0 & 0.0 & 1.7 & 0.0 & 0.5 & 0.0 & 0.5 & 0.0 & 0.0 & \\
\hline 5 & & & & & & & & & & & & & & 0.0 & 0.0 & 0.0 & 0.1 & 0.0 & 0.0 & 0.0 & 0.7 & 0.0 & \\
\hline 6 & 0.6 & 0.0 & 0.4 & 0.5 & 0.5 & 0.4 & 1.2 & 0.6 & 0.5 & 1.3 & 1.7 & 0.1 & 0.5 & 0.2 & 0.0 & 0.1 & 0.0 & 0.01 & 0.1 & 0.1 & 0.0 & 0.05 & -88.5 \\
\hline 7 & 0.2 & 0.2 & 0.1 & 0.3 & 0.1 & 1.2 & 0.4 & 0.1 & 0.4 & 0.2 & 0.0 & 0.4 & 0.4 & 0.3 & 0.6 & 0.4 & 0.2 & 0.3 & 0.1 & 0.3 & 0.2 & 0.0 & \\
\hline 8 & 0.0 & 0.0 & 0.6 & 0.0 & 0.0 & 2.5 & 0.0 & 3.3 & & 0.2 & 0. & & 0.0 & 0.0 & & & & 0 & & & .5 & 0.0 & \\
\hline 9 & 0.8 & 1.5 & 1.8 & 1.3 & 1.3 & 1.4 & 0.9 & 0.4 & 1.6 & 1.8 & 1.5 & 0.8 & 0.6 & 1.3 & 0.4 & 1.1 & 0.2 & 0.4 & 0.8 & 0.6 & 0.4 & 1.3 & -44.5 \\
\hline 10 & 1.6 & 0.8 & 0.3 & 2.0 & 0.8 & 0.5 & 0.4 & 1.6 & 1.4 & 2.1 & 0.3 & 1.2 & 2.5 & 1.5 & 0.7 & 2.0 & 0.4 & 0.9 & 0.8 & 1.5 & 1.4 & 0.6 & \\
\hline 11 & 1.4 & 0.5 & 1.6 & 0.5 & 0.6 & 0.8 & 0.3 & 0.5 & 0.6 & 0.4 & 0.2 & 0.6 & 1.1 & 2.5 & 0.0 & 0.2 & 0.3 & 0.4 & 0.6 & 0.2 & 0.1 & 0.1 & \\
\hline 15 & & & & & & & & & & & & 0.0 & 0.0 & 0.0 & 0.0 & 0.4 & 0.0 & 0.0 & 0.2 & 0.0 & 0.0 & 0.0 & \\
\hline 16 & 1.0 & 0.5 & 1.8 & 1.8 & 2.4 & 0.5 & 2.9 & 0.5 & 1.0 & 3.3 & 1.3 & 1.8 & 0.8 & 1.1 & 1.2 & 1.7 & 1.4 & 0.4 & 1.0 & 2.0 & 0.8 & 1.4 & \\
\hline $17 \mathrm{a}$ & 0.3 & 0.03 & 0.6 & 0.4 & 0.4 & 13.5 & 3.8 & 1.3 & 8.3 & 1.6 & 2.4 & 4.3 & 4.6 & 1.2 & 0.9 & 0.3 & 0.7 & 1.0 & 0.7 & 1.2 & 2.4 & 2.3 & \\
\hline $17 \mathrm{~b}$ & & & 0.1 & 0.1 & 0.0 & & 0.8 & 0.3 & 0.5 & 0.6 & 0.4 & 0.5 & 0.7 & 0.5 & 0.6 & 2. & 0.4 & 0.0 & 0.5 & 0.7 & 0.2 & 0.7 & \\
\hline 18 & 0.1 & 0.2 & 1.1 & 1.2 & 0.9 & 9.2 & 1.0 & 0.9 & 3.9 & 1.9 & 0.3 & 1.2 & 1.6 & 3.4 & 4.4 & 0.9 & 0.9 & 0.7 & 1.1 & 1.8 & 1.0 & 0.5 & \\
\hline 19 & 0.5 & 2.9 & 0.9 & 0.1 & 3.1 & 2.0 & 0.5 & 1.0 & 15.1 & 1. & 8. & 3.0 & 1.2 & 1.0 & 4.7 & 1.3 & 2.2 & 2.9 & 4.0 & 3.3 & 1.7 & 1.7 & \\
\hline 20 & 0.0 & 0.1 & 0.7 & 0.0 & 0.5 & 1.4 & 1.1 & 0.8 & & 5.9 & 0.0 & 0.0 & 0.1 & & 0.1 & & & & & & 0.9 & & \\
\hline 22 & 0.9 & 0.3 & 1.0 & 1.2 & 0.7 & 0.9 & 0.9 & 0.7 & & 2.5 & 1.5 & 1.8 & 1.0 & & 1.2 & & & & & & 8.3 & & 999.3 \\
\hline 23 & 5.3 & 0.8 & 1.4 & 1.1 & 12.8 & 3.9 & 0.6 & 3.8 & & 9.6 & 3.2 & 3.0 & 1.5 & & 3.0 & & & & & & 0.7 & & \\
\hline 25 & & & & & & & & & & & & 0.4 & 0.3 & 0.2 & 0.1 & 0.2 & 0.1 & 0.2 & 0.2 & 2.3 & & 0.2 & \\
\hline
\end{tabular}

Appendix 8. - Trigla lyra. Mean MEDITS biomass index $\left(B I_{y}: \mathrm{kg} \mathrm{km}^{-2}\right)$ per GSA and year from 1994 to 2015 in the $90-445 \mathrm{~m}$ depth range where $90 \%$ of positive hauls occurred. The proportional rate of change (\% change) in $B I_{y}$ was calculated between the first and the last three years of the time series in the GSAs where a significant linear trend in $B I_{y}$ was found.

$\begin{array}{lllllllllllllllllllllllllllll}\text { GSA } & 94 & 95 & 96 & 97 & 98 & 99 & 00 & 01 & 02 & 03 & 04 & 05 & 06 & 07 & 08 & 09 & 10 & 11 & 12 & 13 & 14 & 15 & \text { change }\end{array}$

\begin{tabular}{|c|c|c|c|c|c|c|c|c|c|c|c|c|c|c|c|c|c|c|c|c|c|c|c|}
\hline $\begin{array}{l}1 \\
5\end{array}$ & 0 & 0 & 0.18 & 0.1 & 0 & 0 & 0 & 0 & 0.07 & 0 & 0 & 0.01 & 0.2 & $\begin{array}{l}0.23 \\
17.5\end{array}$ & $\begin{array}{r}0 \\
27\end{array}$ & $\begin{array}{l}0.13 \\
29.5\end{array}$ & $\begin{array}{r}0 \\
21.5\end{array}$ & $\begin{array}{l}0.08 \\
35.9\end{array}$ & $\begin{array}{r}0 \\
22.9\end{array}$ & $\begin{array}{r}0 \\
24.2\end{array}$ & $\begin{array}{l}0.05 \\
29.1\end{array}$ & $\begin{array}{l}0.25 \\
16.6\end{array}$ & \\
\hline 6 & 0.77 & 2.15 & 1.86 & 2.11 & 5.02 & 0.82 & 8.81 & 1.49 & 0.8 & 0.89 & 1.19 & 1.44 & 4.01 & 2.62 & 0.45 & 3.74 & 0.61 & 5.32 & 2.46 & 1.95 & 3.76 & 2.19 & \\
\hline 7 & 6.07 & 34 & 20.5 & 14.6 & 9.41 & 27.9 & 37.4 & 30.5 & 19.5 & 36.9 & 18.6 & 29.6 & 16.6 & 16.8 & 12.7 & 31.8 & 20.2 & 29.9 & 26.4 & 31.6 & 36.5 & 32.7 & \\
\hline 8 & 7.94 & 34.4 & 17.5 & 30 & 8.81 & 4.88 & 5.5 & 0.21 & & 4.67 & 9.59 & 6.71 & 9.18 & 6.19 & 12.2 & 6.05 & 5.39 & 2 & 2.15 & 4.28 & 7.17 & 3.92 & -74.3 \\
\hline 9 & 0.94 & 2.22 & 1.28 & 0.92 & 0.77 & 0.55 & 0.91 & 0.48 & 0.82 & 1.35 & 1.82 & 0.93 & 1.15 & 0.87 & 2.14 & 5.12 & 2.14 & 1.24 & 0.7 & 5.7 & 2.25 & 1.37 & 110.1 \\
\hline 10 & 0.17 & 0.26 & 0.11 & 0.15 & 4.81 & 0.3 & 0.2 & 0.44 & 0.2 & 0.9 & 1 & 0.75 & 0.46 & 1.72 & 0.51 & 1.32 & 2.7 & 0.85 & 0.91 & 0.92 & 0.82 & 0.13 & \\
\hline 11 & 3.39 & 1.93 & 4.63 & 3.78 & 3.08 & 1.3 & 1.09 & 2.83 & 2.67 & 3.24 & 4.58 & 5.62 & 1.77 & 5.19 & 2.79 & 1.92 & 1.9 & 2.85 & 1.84 & 1.22 & 1.18 & 2.27 & \\
\hline 15 & & & & & & & & & & & & 3.25 & 14.2 & 4.94 & 10.6 & 17.7 & 12.1 & 59.6 & 13.7 & 27.4 & 44.5 & 21.3 & 317 \\
\hline 16 & 0.08 & 0.23 & 0 & 0.02 & 0.57 & 0.53 & 0.32 & 2.34 & 0.72 & 1.58 & 1.25 & 3.02 & 2.96 & 7.14 & 5.5 & 35 & 4.66 & 4.98 & 5.67 & 7.45 & 6.08 & 6.59 & 64 \\
\hline $17 \mathrm{a}$ & 0 & 0.12 & 0.37 & 0.2 & 0.08 & 0.32 & 0.11 & 0.09 & 0.21 & 0.23 & 0.39 & 0.15 & 0.31 & 0.26 & 0.33 & 0.12 & 0.1 & 0.08 & 0.05 & 0.04 & 0.18 & 0.09 & \\
\hline $17 b$ & & & 0.97 & 0.89 & 0.2 & & 0.43 & 0.73 & 0.59 & 0.66 & 0.32 & 0.22 & 0.47 & 0.96 & 1.03 & 2.87 & 0.3 & 0.13 & 0.1 & 0.18 & 0.19 & 1.46 & \\
\hline 18 & 0.23 & 0.05 & 0.48 & 0.39 & 0.06 & 0.25 & 0.38 & 0.6 & 0.68 & 0.6 & 1.89 & 0.68 & 0.46 & 0.57 & 1.55 & 1.26 & 1.64 & 0.41 & 0.95 & 0.25 & 0.36 & 0.1 & \\
\hline 19 & 0.21 & 0.41 & 0.08 & 0.3 & 0 & 0.15 & 0.02 & 0.11 & 0.32 & 0.07 & 0.27 & 0.21 & 0.79 & 0.48 & 0.28 & 0.21 & 0.27 & 0.32 & 3.01 & 1.51 & 0.37 & 0.55 & 248.1 \\
\hline 20 & 2.08 & 0 & 0.13 & 0.74 & 0.62 & 1.3 & 0.74 & 1.43 & & 0.6 & 2.77 & 6.2 & 2.54 & & 3.05 & & & & & & 1.52 & & \\
\hline 22 & 9.08 & 4.55 & 3.4 & 1.39 & 6.47 & 15.5 & 6.92 & 2.16 & & 11.1 & 6.62 & 2.76 & 4.26 & & 1.98 & & & & & & 1.54 & & \\
\hline 23 & 7.13 & & 6.98 & 0 & 0 & 0 & 0.49 & 0 & & 0 & 0 & 0 & 0 & & 0 & & & & & & 0 & & \\
\hline 25 & & & & & & & & & & & & 0 & 0.11 & 0.53 & 0.06 & 0.53 & 0 & 0 & 0 & 0 & & 0 & \\
\hline
\end{tabular}


$116 \cdot$ F. Colloca et al..

Appendix 9. - Chelidonichthys lastoviza. Mean MEDITS biomass index (BI: $\mathrm{kg} \mathrm{km}^{-2}$ ) per GSA and year from 1994 to 2015 in the $25-120 \mathrm{~m}$ depth range where $90 \%$ of positive hauls occurred. The proportional rate of change (\% change) in $B I_{y}$ was calculated between the first and the last three years of the time series in the GSAs where a significant linear trend in $B I_{y}$ was found.

\begin{tabular}{|c|c|c|c|c|c|c|c|c|c|c|c|c|c|c|c|c|c|c|c|c|c|c|c|}
\hline GSA & 94 & 95 & 96 & 97 & 98 & 99 & 00 & 01 & 02 & 03 & 04 & 05 & 06 & 07 & 08 & 09 & 10 & 11 & 12 & 13 & 14 & & $\begin{array}{c}\% \\
\text { change }\end{array}$ \\
\hline 1 & 1.0 & 5.9 & 1.8 & 0.8 & 0.6 & 9.5 & 1.3 & 0.9 & 0.7 & 0.3 & 9.7 & 2.2 & 35.7 & 20.1 & 2.0 & 5.6 & 0.1 & 0.5 & 1.0 & 0.2 & 2.7 & 0.9 & \\
\hline & & & & & & & & & & & & & & & 23.3 & 16.6 & & 64.4 & 56.2 & 17.9 & 61.9 & 23.8 & \\
\hline 6 & 1.5 & 1.5 & 1.1 & 1.5 & 4.0 & 4.1 & 3.6 & 4.4 & 0.9 & 0.1 & 1.5 & 1.8 & 2.1 & 5.5 & 4.1 & 8.1 & 13.6 & 18.1 & 2.2 & 11.7 & 7.1 & 4.2 & 357.2 \\
\hline & 0.7 & 0. & & 0. & 0.2 & 0.2 & 0.4 & 0.7 & & & & 0.0 & 0.3 & 0.1 & 0.1 & .0 & 0.2 & 0.0 & 0.0 & 0.1 & .1 & 0.1 & \\
\hline & 10.0 & 10.5 & 7.5 & 28.1 & 3.8 & 5.6 & 1.2 & 2.3 & & 7.3 & 2.6 & 8 & 6.0 & 5.5 & 8.1 & 5.2 & 0.0 & 7.4 & 8.1 & 7.9 & 5.2 & 2.1 & \\
\hline & 0.1 & 0.4 & 0.6 & & 0.8 & 1.0 & 0.6 & 0.2 & 0.2 & 0.1 & 0 & 0 & 0.1 & 0.0 & 0.3 & 0.2 & & & 0.4 & 0.0 & 0.1 & 0.0 & \\
\hline 10 & 3.9 & 1.6 & 0.8 & 1.1 & 1.5 & 1.9 & 2.3 & 0.3 & 0.3 & 1.4 & 0.3 & 0.4 & 0.4 & 1.8 & 0.5 & 0.2 & 0.3 & 0.5 & 0.1 & 0.2 & 0.1 & 0.0 & -90.4 \\
\hline 11 & 0.0 & 0.0 & 7.5 & 17.2 & 11.6 & 15.3 & 0.0 & 0.0 & 18.0 & 11.6 & 11.9 & 16.3 & 12.6 & 31.3 & 10.3 & 10.1 & 13.4 & 11.4 & 12.8 & 3.6 & 4.8 & 1.7 & \\
\hline 15 & & & & & & & & & & & & 5.6 & 25.4 & 31.9 & 30.7 & 25.9 & 8.4 & 21.6 & 2.5 & 27.11 & 111.0 & 39.8 & \\
\hline 16 & 1.7 & 5.5 & 9.3 & 13.5 & 8.9 & 5.5 & 8.5 & 10.1 & 4.2 & 5.0 & 7. & & 3.0 & 4.4 & 4.9 & 5 & & & 4.5 & 3.3 & 0.4 & 2.5 & -60.3 \\
\hline $17 \mathrm{a}$ & 2.9 & 0.1 & 3.5 & 1.4 & 1.4 & 1.1 & 4.2 & 2. & 0. & 0.7 & 0.6 & 0.5 & 0.2 & 0.3 & 0.7 & 0 & 0.6 & 0. & 0.7 & 0.4 & 0.8 & 0.7 & -69.1 \\
\hline $17 \mathrm{~b}$ & & & & & & & 4.4 & & & & & & & 3.5 & 4.0 & & & & & & & 2.3 & -28 \\
\hline 18 & 0.2 & 0.0 & 0.1 & 0.0 & 0.0 & 0.3 & 0.1 & 0.3 & 0.8 & 0.2 & 0.2 & 0.5 & 0.1 & 0.0 & 0.0 & 0.5 & 1.4 & 0. & 1.1 & & 0.2 & 0.1 & \\
\hline 19 & & 0.1 & 0. & & & 0.2 & 0.6 & & & 1.9 & & & 0.7 & 0.1 & 0.4 & 0.1 & 0.8 & 0.9 & 0.9 & 0. & 0.4 & 0.7 & \\
\hline 20 & 0.9 & 0.0 & 25.6 & 19.5 & 1.2 & 0.8 & 1.7 & 1.9 & & 2.4 & 2.6 & 4.8 & 5.0 & & 5.4 & & & & & & 5.4 & & \\
\hline 22 & 5.1 & 16.1 & 14.2 & 7.1 & & 11.2 & 11.2 & 7.3 & & 25.4 & 12.1 & & & & 20.7 & & & & & & & & \\
\hline 23 & 0.7 & 0.0 & 1.8 & 0.0 & 0.0 & 3.7 & 8.2 & 1.8 & & 7.9 & 3.5 & 13.4 & 3.2 & & 6.5 & & & & & & 16.6 & & 1269.0 \\
\hline 25 & & & & & & & & & & & & 3.6 & 3.0 & 5.6 & 3.6 & 2.0 & 1.1 & 3.2 & 3.8 & 5.0 & & 9.4 & \\
\hline
\end{tabular}

Appendix 10. - Peristedion cataphractum. Mean MEDITS biomass index $\left(B I_{v}: \mathrm{kg} \mathrm{km}^{-2}\right)$ per GSA and year from 1994 to 2015 in the $115-550$ $m$ depth range where $90 \%$ of positive hauls occurred. The proportional rate of change (\% change) in $B I_{y}$ was calculated between the first and the last three years of the time series in the GSAs where a significant linear trend in $B I_{y}$ was found.

\begin{tabular}{|c|c|c|c|c|c|c|c|c|c|c|c|c|c|c|c|c|c|c|c|c|c|c|c|}
\hline GSA & 94 & 95 & 96 & 97 & 98 & 99 & 00 & 01 & 02 & 03 & 04 & 05 & 06 & 07 & 08 & 09 & 10 & 11 & 12 & 13 & 14 & 15 & $\begin{array}{c}\% \\
\text { change }\end{array}$ \\
\hline 1 & 0.0 & 0.6 & 0.1 & 0.1 & 0.1 & 0.0 & 0.1 & 0.2 & 0.6 & 0.2 & 0.0 & 0.0 & 0.1 & 0.2 & 0.2 & 0.2 & 0.0 & 0.5 & 0.3 & 0.1 & 0.2 & 0.2 & \\
\hline 5 & & & & & & & & & & & & & & 0.7 & 1.1 & 2.0 & 1.4 & 1.8 & 1.8 & 3.1 & 0.7 & 1.0 & \\
\hline 6 & 0.0 & 0.2 & 1.1 & 0.2 & 0.1 & 0.0 & 0.2 & 2.5 & 0.4 & 0.0 & 0.1 & 0.0 & 1.1 & 0.7 & 0.7 & 1.0 & 0.2 & 2.6 & 1.1 & 0.7 & 0.3 & 0.4 & \\
\hline 7 & 0.1 & 14.7 & 0.0 & 0.0 & 3.4 & 3.3 & 2.6 & 0.1 & 0.0 & 1.7 & 0.8 & 0.1 & 0.1 & 1.7 & 0.0 & 1.6 & 0.4 & 0.0 & 0.9 & 0.0 & 0.1 & 0.2 & \\
\hline 8 & 1.6 & 2.2 & 3.9 & 2.1 & 1.6 & 3.7 & 2.5 & 5.0 & & 3.5 & 7.3 & 4.4 & 8.6 & 5.8 & 3.3 & 3.5 & 1.6 & 2.2 & 3.9 & 4.2 & 3.3 & 3.1 & \\
\hline 9 & 0.2 & 0.1 & 0.2 & 0.3 & 0.2 & 0.1 & 0.2 & 0.2 & 0.2 & 0.3 & 0.2 & 0.1 & 0.1 & 0.3 & 0.1 & 0.3 & 0.3 & 0.3 & 0.2 & 0.2 & 0.4 & 0.2 & \\
\hline 10 & 0.3 & 0.9 & 0.4 & 2.3 & 2.4 & 2.0 & 1.3 & 1.1 & 0.5 & 3.6 & 1.3 & 2.3 & 2.4 & 0.4 & 2.9 & 2.0 & 1.6 & 0.7 & 0.8 & 1.6 & 0.8 & 0.4 & \\
\hline 11 & 5.7 & 6.5 & 5.2 & 8.1 & 10.2 & 5.3 & 4.3 & 10.5 & 12.8 & 6.9 & 1.4 & 8.4 & 0.4 & 0.3 & 0.6 & 0.7 & 0.6 & 0.5 & 0.9 & 0.6 & 0.2 & 0.6 & -91.5 \\
\hline 15 & & & & & & & & & & & & 15 & 20.3 & 3.3 & 60.0 & 42.4 & 44.6 & 41.9 & 27.4 & 16.0 & 25.9 & 40.1 & \\
\hline 16 & 0.1 & 0.2 & 0.4 & 0.2 & 0.5 & 0.6 & 0.4 & 0.6 & 4.5 & 1.4 & 0.8 & 0.4 & 0.8 & 1.4 & 3.1 & 5.8 & 3.6 & 2.7 & 2.3 & 1.8 & 0.1 & 1.1 & 315.2 \\
\hline $17 \mathrm{a}$ & 0.0 & 0.0 & 0.01 & 0.0 & 0.0 & 0.01 & 0.0 & 0.01 & 0.01 & 0.0 & 0.0 & 0.0 & 0.0 & 0.0 & 0.0 & 0.0 & 0.0 & 0.0 & 0.0 & 0.02 & 0.04 & 0.05 & 1333.1 \\
\hline $17 b$ & & & 0.0 & 0.0 & 0.0 & & 0.0 & 0.0 & 0.0 & 0.1 & 0.0 & 0.0 & 0.01 & 0.0 & 0.0 & 0.0 & 0.0 & 0.0 & 0.0 & 0.0 & 0.0 & 0.0 & \\
\hline 18 & 0.0 & 0.0 & 0.0 & 0.0 & 0.1 & 0.1 & 0.1 & 0.4 & 0.1 & 0.3 & 0.4 & 0.3 & 0.1 & 0.3 & 0.3 & 0.4 & 0.7 & 0.5 & 0.8 & 0.4 & 0.7 & 0.7 & 5469.0 \\
\hline 19 & 0.0 & 0.1 & 0.3 & 0.1 & 0.0 & 0.0 & 0.1 & 0.0 & 0.0 & 0.2 & 0.1 & 0.1 & 0.3 & 0.0 & 0.0 & 0.3 & 0.3 & 0.4 & 0.2 & 1.8 & 0.0 & 0.5 & 523.8 \\
\hline 20 & 13.0 & 0.0 & 12.0 & 0.4 & 6.5 & 20.9 & 10.5 & 16.6 & & 13.7 & 6.9 & 10.9 & 12.3 & & 18.5 & & & & & & 3.4 & & \\
\hline 22 & 0.8 & 0.7 & 0.6 & 0.2 & 1.7 & 3.4 & 1.5 & 0.8 & & 1.9 & 2.7 & 1.2 & 1.4 & & 0.8 & & & & & & 0.5 & & \\
\hline 23 & 0.6 & 0.0 & 3.8 & 0.0 & 0.0 & 0.0 & 0.1 & 0.0 & & 0.0 & 0.0 & 0.0 & 0.0 & & 0.0 & & & & & & 0.0 & & \\
\hline 25 & & & & & & & & & & & & 0.0 & 0.2 & 0.0 & 0.0 & 0.0 & 0.0 & 0.0 & 0.0 & 0.6 & & 2.3 & 1760.1 \\
\hline
\end{tabular}

